\title{
Genetic Addiction Risk Score (GARS): Molecular Neurogenetic Evidence for Predisposition to Reward Deficiency Syndrome (RDS)
}

\author{
Kenneth Blum • Marlene Oscar-Berman • \\ Zsolt Demetrovics • Debmalya Barh • Mark S. Gold
}

Received: 9 December 2013 / Accepted: 29 April 2014 /Published online: 31 May 2014

(C) The Author(s) 2014. This article is published with open access at Springerlink.com

\begin{abstract}
We have published extensively on the neurogenetics of brain reward systems with reference to the genes related to dopaminergic function in particular. In 1996, we coined "Reward Deficiency Syndrome" (RDS), to portray behaviors found to have gene-based association with hypodopaminergic function. RDS as a useful concept has been embraced in many subsequent studies, to increase our understanding of Substance Use Disorder (SUD), addictions, and other obsessive, compulsive, and impulsive behaviors. Interestingly, albeit others, in one published study, we were able to describe lifetime RDS behaviors in a recovering addict (17 years sober) blindly by assessing resultant Genetic Addiction Risk Score (GARS ${ }^{\mathrm{TM}}$ ) data only. We hypothesize that genetic testing at an early age may be an effective preventive strategy to reduce or eliminate pathological substance and behavioral seeking activity. Here, we consider a select number of genes, their polymorphisms, and associated risks for RDS
\end{abstract}

\section{K. Blum $(\varangle) \cdot$ M. S. Gold}

Department of Psychiatry \& McKnight Brain Institute, University of

Florida College of Medicine, Gainesville, FL, USA

e-mail: drd2gene@gmail.com

\section{Oscar-Berman}

Departments of Psychiatry, Neurology, and Anatomy \&

Neurobiology, Boston University School of Medicine, and Boston

VA Healthcare System, Boston, MA 02118, USA

\section{K. Blum}

Department of Holistic Medicine, National Institute for Holist

Addiction Studies, North Miami Beach, FL, USA

K. Blum

Human Integrated Services Unit University of Vermont Center for Clinical \& Translational Science, College of Medicine, Burlington, VT, USA

K. Blum

Dominion Diagnostics, LLC, North Kingstown, RI, USA whereby, utilizing GWAS, there is evidence for convergence to reward candidate genes. The evidence presented serves as a plausible brain-print providing relevant genetic information that will reinforce targeted therapies, to improve recovery and prevent relapse on an individualized basis. The primary driver of RDS is a hypodopaminergic trait (genes) as well as epigenetic states (methylation and deacetylation on chromatin structure). We now have entered a new era in addiction medicine that embraces the neuroscience of addiction and RDS as a pathological condition in brain reward circuitry that calls for appropriate evidence-based therapy and early genetic diagnosis and that requires further intensive investigation.

Keywords Genetic Addiction Risk Score (GARS) ${ }^{\mathrm{TM}}$. Polymorphisms $\cdot$ brain reward circuitry $\cdot$ Reward Deficiency Syndrome (RDS) · Neurogenetics

\footnotetext{
K. Blum

Department of Addiction Research \& Therapy, Malibu Beach

Recovery Center, Malibu Beach, CA, USA
}

K. Blum

Department of Clinical Neurology, PATH Foundation, New York, NY, USA

K. Blum • D. Barh

Institute of Integrative Omics and Applied Biotechnology, Nonakuri, Purba Medinipur, West Bengal, India

K. Blum

IGENE, LLC, Austin, TX, USA

\section{Z. Demetrovics}

Department of Clinical Psychology and Addiction, Eötvös Loránd University, Institute of Psychology, Budapest, Hungary 


\section{The Role of Dopaminergic Genetics in Reward Dependence}

Neurotransmitter interactions regulate brain reward circuitry that result in the release of dopamine (DA) in the major loci for feelings of well-being and reward, the nucleus accumbens (NAc) part of the mesolimbic system of the brain. The interrelationship of at least four important neurochemical pathways: serotonergic, endorphinergic, GABAergic, and dopaminergic constitute the "brain reward cascade" (see Fig. 1) a natural sequence of events that produce feelings of well being. These activities including: the synthesis, vesicle storage, metabolism, release, and function of neurochemicals [1] are regulated by genes, and their expression, in terms of messenger RNA-directed proteins. Thus, genetic testing is a potential window that can be used to identify the specific neurochemistry of individuals and formulate the best treatment options for them [1-13].

DA is a neurotransmitter with multiple important functions including behavioral effects such as "pleasure" and "stress reduction." Simply stated, without the normal function of this substance, an individual will suffer from cravings and have an inability to cope with stress. Thus, genetic hypodopaminergic brain function predisposes individuals to seek substances and or behaviors that can be used to overcome this craving state by activating the mesolimbic dopaminergic centers $[4,13]$. Psychoactive substances like alcohol, psychostimulants and opiates, and risky behaviors like gambling, overeating and thrill seeking [16] induce the release of neuronal DA into the synapse at the NAc, to overcome the hypodopaminergic state of that individual. Temporary relief from the discomfort and a pseudo sense of well-being is the product of this selfmedication [17]. Unfortunately, chronic abuse of psychoactive substances leads to inactivation, or a downregulation, like for example, inhibition of neurotransmitter synthesis, neurotransmitter depletion, formation of toxic pseudo neurotransmitters, and through structural receptor dysfunction. Therefore, substance-seeking and pathological behaviors are both used as a means of providing a feel-good response (a "fix") to lessen uncontrollable cravings. Individuals who possess reward gene polymorphisms or variations, will, given environmental insult be at risk for impulsive, compulsive, and addictive behaviors. Reward Deficiency Syndrome (RDS) is a term used to embrace and characterize these genetically induced behaviors. Any and all of these pathological behaviors, as well as psychoactive drug-abuse, are candidates for addiction including tolerance and dependence. The behavior or drug of choice by the individual is a function of both genes and environmental factors like availability and peer pressure.

\section{Brain Reward Cascade Explanation}

DA is crucial to the maintenance of natural rewards while the release of DA into NAc synaptic sites is a somewhat complex cascade of reactive activity that involves neurotransmitters and structures in the limbic system [1]. Blum and Kozlowski first proposed the concept of a "brain reward cascade" in 1990 as a cascade of interactive events and mesolimbic function that produces the net release of DA [1] (see Fig. 1). Simply, the interaction of activities in the separate subsystems of the brain's reward circuitry combine into the much larger global system, and reveal the cascade of neurotransmission, which merges simultaneously and in a specific sequence. When these systems work normally, they result in a feeling of pleasure, well-being, and peace; an imbalance, or deficiency, on the other hand, will cause the system to function abnormally, displacing the sense of well-being with negative feelings like anxiety, anger, and low self-esteem. The need to mask these negative feelings leads to the use of substances such as alcohol and narcotics, meaning that excessive desires are spurred by the need for DA.
Fig. 1 Brain Reward Cascade $[14,15]$. In this cascade, stimulation of the serotonergic system in the hypothalamus leads to the stimulation of delta/mu receptors by serotonin to cause a release of enkephalin. Activation of the enkephalinergic system induces an inhibition of GABA transmission at the substania nigra by enkephalin stimulation of $\mathrm{mu}$ receptors at GABA neurons. This inhibitory effect allows for the fine-tuning of GABA activity. This provides the normal release of dopamine at the projected area of the NAc $[14,15]$

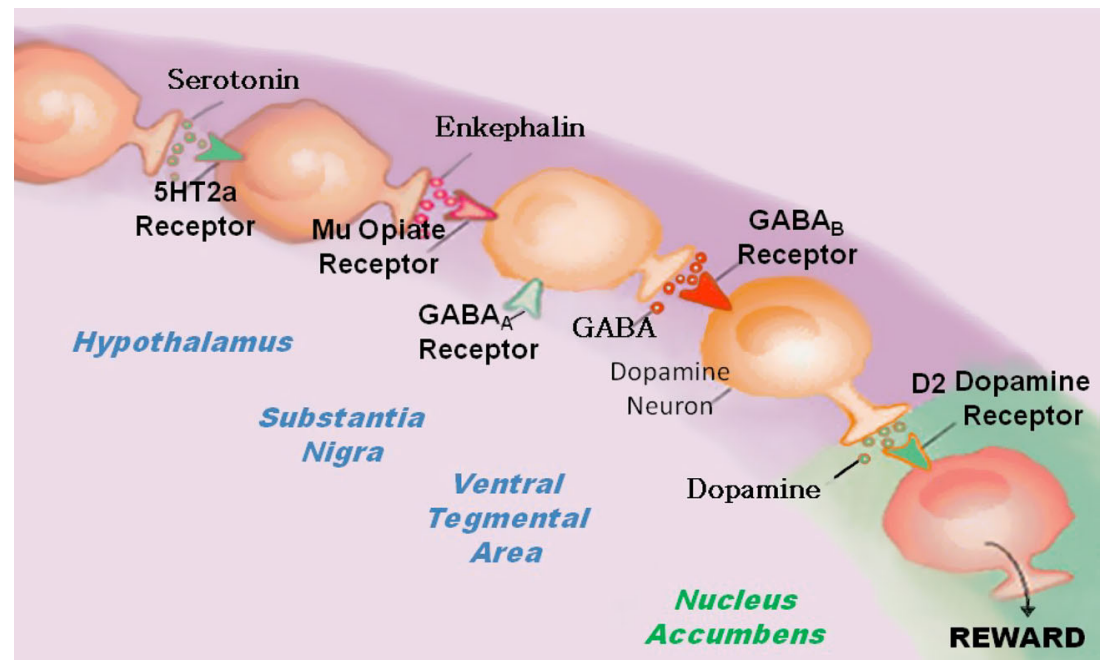


The DA pathway arises in the ventral tegmental area (VTA) and culminates in the DA D2 receptors on neurons located in the cell membranes of in the hippocampus and the NAc. Blum and Kozlowski [1] describe a process that begins in the hypothalamus, where the excitatory activities of 5-HTreleasing-neurons cause the release of met-enkephalin, an opioid peptide. The opioid peptide regulates the activity of neurons responsible for the release of gamma-aminobutyric acid (GABA) the inhibitory neurotransmitter at the substantia nigra. When DA-containing neurons in the VTA, and in certain parts of the hippocampus via the amygdala, are disinhibited, DA is allowed to be released into the NAc, permitting the completion of the cascade. If the cascade is functioning correctly, the reward sensation, or the feeling of well-being, is experienced, provided certain basic genetic conditions are fulfilled (see Fig. 1) [1]. However, when the genes that govern the function of the brain reward cascade have polymorphic variations, these risk alleles provide the basis for therapeutic targets.

\section{RDS and Genetic Antecedents}

The development of a blueprint for identifying certain candidate genes and polymorphisms that could negatively impact DA release is based on this understanding of the brain reward cascade [2]. Many genes are involved, and it has been adequately established in association studies and animal research literature that, for example, polymorphisms of the serotonergic-2 A receptor (5-HTT2a), DA D2 receptor (DRD2), and the catechol-O-methyl-transferase (COMT) genes (see Genetic Addiction Risk Score (GARS) test), predispose individuals to aberrant RDS behaviors. These behaviors include craving not only for drugs and alcohol but eating and other addictive behaviors such as pathological gambling (see Table 1) [3]. Gene polymorphisms of both 5-HT and DA can result in significantly lower than normal receptor densities. A COMT gene polymorphism can result in increased catabolism of synaptic DA and subsequent reduction of DA function. These are three examples of how the identification of polymorphisms on these three genes can provide a window into an impaired brain reward cascade, and the identification of individuals at high risk can be accomplished. Based on a published [11] mathematical Bayesian approach, it was found that individuals who carry the Taq A1 polymorphisms of the DRD2 have a $74.4 \%$ chance of developing RDS behaviors, given an environmental insult and epigenetic effects (see Table 1).

\section{Genomics: Evidence-Based Studies}

In general, inconsistencies in the literature involving association studies using single gene analysis prompted Conner [4] and others to evaluate a number of dopaminergic gene polymorphisms as predictors of drug use in adolescents. We cannot ignore the importance of neurochemical mechanisms involved in drug-induced relapse behavior, as suggested by Bossert et al. [5] for understanding the interaction of multiple genes and environmental elements. Using a drug relapse model previously shown to induce relapse by reexposing rats to heroin-associated contexts, these investigators found that after extinction of drug-reinforced responding in different contexts, re-exposure reinstated heroin seeking. This effect was diminished by inhibition of GABA transmission in the VTA and medial accumbens shell and components of the mesolimbic DA system; this process enhances net DA release into the NAc. Indeed, this fits well with Li's Knowledgebase for Addiction-Related Genes (KARG) addiction network map [6] (see Fig. 2). Li et al. [6] also stressed the view that drug addiction is a serious problem worldwide with strong genetic and environmental influences. And that a variety of technologies were used to discover genes and pathways that underlie addiction

Table 1 Reward deficiency syndrome behaviors (linked with DSM 5)

\begin{tabular}{|c|c|c|c|c|c|}
\hline \multicolumn{2}{|l|}{ Addictive behaviors } & \multicolumn{2}{|l|}{ Impulsive behaviors } & \multirow{2}{*}{$\begin{array}{l}\text { Obsessive compulsive } \\
\text { behaviors }\end{array}$} & \multirow{2}{*}{$\begin{array}{l}\text { Personality } \\
\text { disorders }\end{array}$} \\
\hline Substance related & Non substance related & Spectrum disorders & Disruptive impulsive & & \\
\hline Alcohol & Thrill seeking (novelty) & Attention-deficit hyperactivity & Anti-social & Body dysmorphic & Paranoid \\
\hline Cannabis & Sexual sadism & Tourette and tic Syndrome & Conduct & Hoarding & Schizoid \\
\hline Opioids & Sexual masochism & Autism & Intermittent explosive & Trichotillomania (hair pulling) & Borderline \\
\hline Sedatives/hypnotics & Hypersexual & & Oppositional defiant & Excoriation (skin picking) & Schizotypal \\
\hline Stimulants & Gambling & & Exhibitionistic & Non-suicidal self-injury & Histrionic \\
\hline Tobacco & Internet gaming & & & & Narcissistic \\
\hline Glucose & & & & & Avoidant \\
\hline Food & & & & & Dependant \\
\hline
\end{tabular}


Fig. 2 KARG an addiction network map [6]

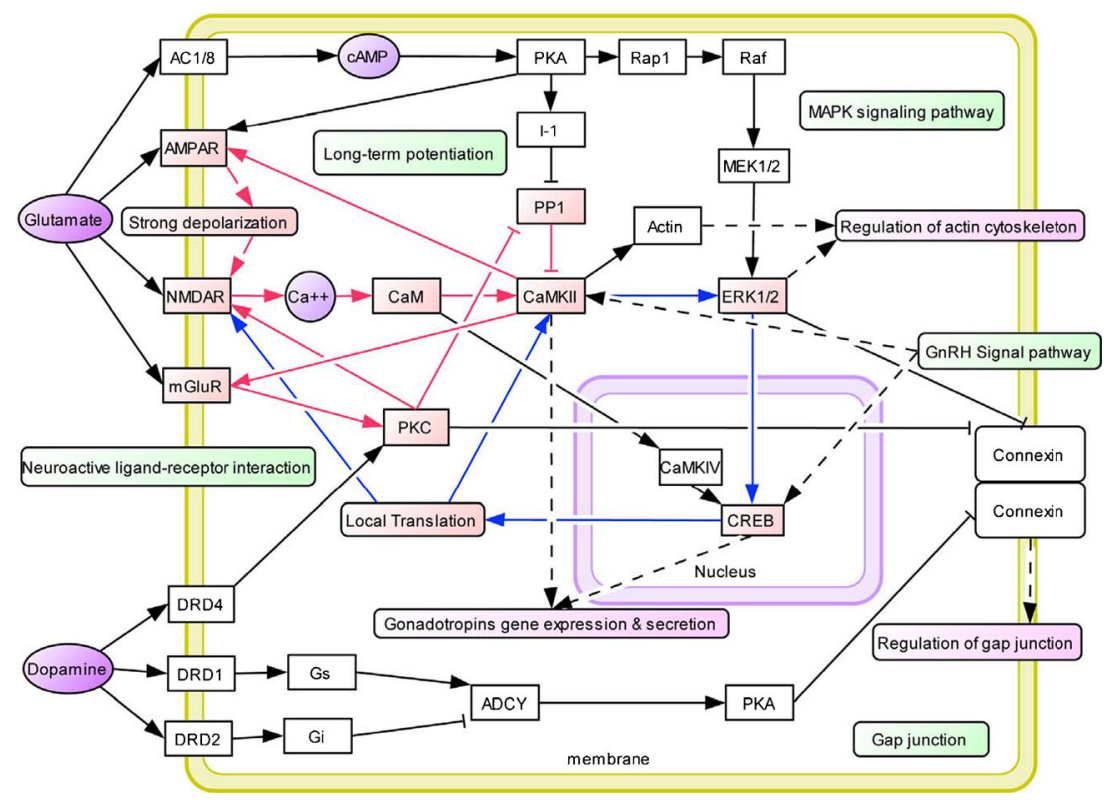

however, each individual technology can be biased and incomplete. Li and his colleagues integrated evidence from peer-reviewed publications 2,343 items between 1976 and 2006 that inked genes and chromosomal regions to addiction by single-gene strategies, microarray, proteomics, or genetic studies. They identified 1,500 human addiction-related genes and developed the first molecular KARG (http://karg.cbi. pku.edu.cn), with a friendly web interface and extensive annotations. Their meta-analysis of 396 genes, each supported by two or more independent items of evidence, leads to the identification of 18 molecular pathways that were statistically significant and covered both upstream signaling events and downstream effects. For four different types of addictive drugs and five significant molecular pathways including two new ones; GnRH signaling pathway and gap junction were identified as common pathways that may underlie shared rewarding and addictive actions. In a hypothetical common molecular network for addiction, they connected the common pathways which linked all of these genes, to both the glutaminergic and dopaminergic pathways.

Following the initial finding of Blum et al. in 1990 [7] showing a positive association of the single gene DRD2 polymorphism in chromosome 11 and severe alcoholism, replication, although favorable has, to date, been fraught with inconsistent results. This has also been true for other complex behaviors [9] when gene-gene and gene-environment interactions are tested the idea that complex gene-relationships may account for inconsistent findings across many different single gene studies is supported [8]. The reasons for inconsistencies in trying to predict drug use are many and varied: they include single gene analysis, poorly screened controls, stratification of population, personality traits, co-morbidity of psychiatric disorders, gender-base differences, positive and negative life events, and neurocognitive dysfunctioning and epigenetic effects $[6,7]$.

In order to gain a more complex but stronger predictive set of genetic antecedents rather than continue to evaluate single gene associations, we embarked on a study to evaluate multiple candidate genes, especially those linked to the Brain Reward Cascade to predict future drug abuse [1] and identify risk for hypodopaminergic functioning. Although exploratory, the goal is to develop an informative panel based on numerous known risk alleles to provide treatment facilities a means of stratifying patients entering treatment as having a high, moderate, or low, genetic risk prediction.

As noted above, an association between dopaminergic gene polymorphisms and addictive, compulsive, and impulsive behaviors classified as RDS has been revealed in numerous studies. We evaluated subjects derived from two families for a potential association with polymorphisms of the DA D2 receptor gene (DRD2), DA D1 receptor gene (DRD1), DA transporter gene (DATl), and DA beta-hydroxylase gene $(D B H)$. This association if found would demonstrate the relevance of a generalized RDS behavior set, as the phenotype.

An experimental group derived from up to five generations of two independent multiple-affected families $n=55$ were genotyped and compared to very rigorously screened controls. In addition to these subjects, data related to RDS behaviors was collected from 13 deceased family members. The genotyped family members carried the DRD2 Taq 1 allele at $78 \%$ the DAT $110 / 10$ allele at $58 \%$, the DBHB1 allele at $66 \%$, and the DRD1 A1/A1 or the A2/A2 genotypes at $35 \%$. Interestingly, all probands $(n=32)$ from Family A genotyped for the 
DRD2 gene carried the TaqA1 allele (100\%). The experimental positive rate for the DRD2 Taq1 allele with an odds ratio of $103.9(12.8,843.2)$ was significantly greater $\left(X^{2}=43.6\right.$, $P<0.001)$. The experimental positive rate for the DAT1 10 / 10 allele with an odds ratio of $2.3(1.2,4.6)$ was also significantly greater $\left(X^{2}=6.0, P<0.015\right)$. Between the experimental and control positive rates of the DBH, DRD1 A1/A1, or A2/ A2 genotypes no significant differences were observed [18].

Patients genetic risk for drug-seeking behavior needs to be evaluated prior to, or upon entry to chemical dependency programs. The importance of genotyping to establish genetic severity for patients undergoing treatment and in danger of relapse is described below in the, as yet, unpublished results from a study of the data from Comprehensive Analysis of Reported Drugs (CARD). We have followed up by evaluating a panel of genes and associated polymorphisms termed GARS in patients with RDS behaviors attending two treatment centers. In this and other studies, we use the GARS for purposes of study identification and commercial testing [9-11].

To determine risk severity of 72 addicted patients, the percentage of prevalence of selected risk alleles was calculated to provide a severity score. We genotyped the patients using a nine reward genes and their polymorphisms $(F=18$ alleles; $M=17$ alleles). This panel included: $D R D$ 2, 3, 4; MOA-A; COMT, DAT1; 5HTTLLR; OPRM1; and GABRA3 genes. The three severity ratings were: Low severity $=1-36 \%$; moderate severity $=37-50 \%$, and high severity $=51-100 \%$. We studied two distinct treatment populations: Group 1 consisted of 37 addicts from a holistic addiction treatment center in North Miami Beach, Florida, and Group 2 consisted of 35 addicts from Malibu Beach Recovery Center [12]. We are in the process of analyzing 393 subjects using a multicentered approach across the USA.

However, in the following unpublished experiment, we found risk stratification of the 72 genotyped patients to be as follows: $27 \%$ low risk; $74 \%$ moderate risk, and $4 \%$ severe risk. We are exploring potential risk correlation with the Addiction Severity Index (ASI). Preliminary statistical analysis reveals that with $N=277$, we found a significant trend whereby allelic risk above the means score associated with the ASI Alcohol Risk Severity Score at $P<0.07$ (one sided P). Unlike CARD, the GARS could provide potential correlations to ASI to at least the alcohol risk composite score. If this finding is upheld through larger populations, it unequivocally demonstrates that objective genetic polymorphisms could predict clinical outcomes.

We are cognizant that, as the next steps in identifying candidate gene polymorphic associations with RDS as the overall phenotype, we must carefully dissect epigenetic effects such as miRNA and subsequent methylation and/or deacetylation of attached chromatin markers leading to altered gene expression in spite of DNA polymorphisms.

\section{CARD $^{\text {TM }}$ Provides a Rationale for Genetic Testing}

The primary reason to include some brief information regarding CARD is to provide a clear indication that genetic testing may provide valuable information about the risk that drives relapse. In an unpublished study but submitted article from our laboratory, a statistical analysis of unidentifiable data from a computer-based program called CARD was used to evaluate treatment adherence in a large clinical cohort from across a number of eastern states in America. This study consisted of 5,703 patients and 11,403 specimens, in various treatment settings across six eastern states. We found significant levels of both non-compliance and lack of abstinence (risk for relapse) during treatment. The CARD engine addresses issues of metabolism as well as contaminants in the production processes of some formulations. It addresses multi-faceted scenarios within and across drug classes, often involving the state of multiple analytes in order to reach a conclusion for each self-reported or prescribed drug. It evaluates thousands of rule sets to determine if the statement associated with each rule set is applicable to the specimen test results and reported drugs that are analyzed.

We are proposing a paradigm shift on the basis of these studies, whereby the predisposition to a risk for RDS (the true phenotype) can be accurately determined by utilizing GARS, and treatment outcome can be assessed by utilizing CARD. These results confirm the putative role of dopaminergic polymorphisms in RDS behaviors.

\section{The Addiction Phenotype and the Need for Super Controls}

The family-based study [18] demonstrates the importance of a nonspecific RDS phenotype and informed an understanding of how evaluating single subset of RDS behaviors, like for example, Tourette's may lead to spurious results. Rather, the adoption of a nonspecific reward phenotype may be useful in future association and linkage studies involving neurotransmitter gene candidates as utilized in GARS. The putative role of dopaminergic polymorphisms in RDS behaviors is supported by the results [18], although linkage analysis is necessary and the sample size was limited. We believe that using a nonspecific reward phenotype in future association and linkage studies that involve dopaminergic polymorphisms and other neurotransmitter gene candidates may be a necessary paradigm shift.

This underscores the problem concerning appropriate controls. While thousands of studies have associated the various reward gene risk polymorphisms for all types of addictive behaviors (including drugs, smoking, alcohol, gambling, sex, shopping) against putative controls, there remains a real need to develop super controls whereby the true phenotype is not just drug addiction per se but the absence of any RDS 
behavior. To suggest that researchers can provide accurate data by enlisting comparison individuals who are from an unscreened general population as controls, is fraught with an inappropriate and potentially inaccurate assessment. In one, example, assessing the DRD2 A1 allele, we found that while screened controls (eliminating drug and alcohol abuse) in over 3,000 subjects showed a prevalence of approximately $26 \%$; when we eliminated all RDS behaviors in the probands and family surprisingly we found the DRD2 A1 allele prevalence to be only $3 \%$ [19]. In the current GARS test being cognizant of this issue, we utilize the recognized method of counting risk alleles to provide addiction risk. Below, we provide a chart showing the remarkable Pub Med (3-16-14) list of articles published on each independent gene involving risk polymorphisms in RDS behavior and controls (Fig. 3).

\section{Theoretical Implications: Substance Abuse and Pain Medications}

Understanding that there is a thread between opioid prescribed compounds for pain and addiction liability especially in subjects genetically predisposed to RDS risk provides the rationale to address this growing epidemic globally. The GARS test modified for pain clinics provides an analysis of about 14 genes and associated risk alleles. Thousands of studies in peer reviewed scientific journals have revealed significant associations between certain reward genes, with reward circuitry imbalances in the brain and risk for high substance seeking behavior. The predictive value for just one gene such as the DA D2 receptor gene is as high as $74.4 \%$ as described by Blum et al. [12]. Simply, the occurrence or absence of these single nucleotide polymorphisms may determine a patient's predisposition to potential treatment outcome and relapse. In addition to addiction risk, it may help guide the physician in determining the use of chronic opioid therapy, and a rationale for continuing urine monitoring consistent with the American College of Occupational and Environmental Medicine (ACOEM) guidelines. Most importantly, ACOEM suggests that genetics are an important factor in pain management, and according to the National Institute on Drug Abuse (NIDA), as well as the American Society of Addiction Medicine (ASAM), genes are responsible for a $60 \%$ contribution toward addictive behaviors. Not surprisingly, according to the American Pain Society, a physician's ability to predict an opioid abuser is no better than chance $(50 \%)$. In fact, Bornstein's group [20] found that when clinicians' only urine test patients suspected of medication misuse, they are missing a significant group; up to $72 \%$ and are quick to make wrong judgments. The ACOEM guidelines on Chronic Opioid Therapy suggest "screening for risk of addiction should be performed before starting a long-term opioid treatment in patients with chronic pain", thus providing the physician with clues about the necessity for increased attention in susceptible patients. If opioid treatment results in pain control, better functioning, and improved health-related quality of life, the treatment should be continued, even in patients susceptible for addiction. However, these patients will need special attention with a focus on compliance, abstinence from other drugs of abuse and with discussion of the potential consequences of chronic treatment of pain with opioids.

Although the principal pain pathways ascend to the brain from the dorsal horn of the spinal cord the control of sensitivity to pain may reside in the mesolimbic system of the brain at the reward center, where gene polymorphisms may impact pain tolerance and/or sensitivity. These polymorphisms may associate with a predisposition to pain intolerance or tolerance to pain. It is hypothesized that the identification of certain gene polymorphisms may provide a unique therapeutic target to assist in pain treatment. Thus, testing for certain candidate genes like the mu receptors and PENK could assist in the design of pharmacogenomic solutions personalized to each patient and guided by their unique genetic makeup [10], with potential for improvement in clinical outcomes [11].
Fig. 3 This is a list of Pub Med articles that associate polymorphisms of reward genes with risk of RDS behaviors. For each gene, there are many polymorphisms, and there are multiple receptors for each listed transmitter. The DRD2 gene is the most widely studied as a single receptor type. Reward Gene Publications 3/16/2014

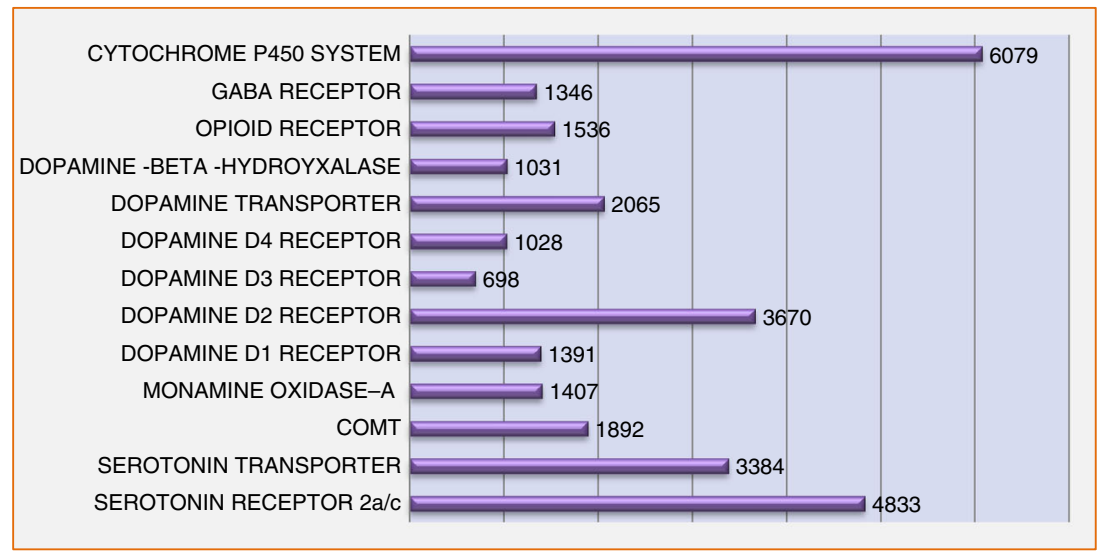


Understanding the role of neurogenetics in pain relief, including pharmacogenomics and nutrigenomic aspects, will pave the way to better treatment for the millions suffering from both acute and chronic pain. We now know that dopaminergic tone is involved in pain sensitivity mechanisms and even buprenorphine outcome response. The identification of certain gene polymorphisms as unique, therapeutic targets may assist in the treatment of pain. Pharmacogenetic testing for certain candidate genes, like mu receptors and PENK, is proposed, as a means to improve clinical outcomes by the provision of treatment. The use of GARS, as described above, to identify clients with high addiction risk by providing valuable information about genetic predisposition to opioid addiction, could become an important frontline approach, on admission to pain clinics.

One notable study evaluated the role of both mu-opioid receptors (MORs) and delta-opioid receptors (DORs) two genes expressed in the VTA that may be involved in the addictive properties of opiates. Researchers David et al. [21] found that intra-VTA morphine self-administration was abolished in knockout MOR gene mice at all doses tested. While male and female WT and DOR- -1 - mice exhibited selfadministration similarly, however, this behavior was disrupted without triggering physical signs of withdrawal by the administration of Naloxone (4 mg/ $\mathrm{kg})$ to WT and DOR mutants. An increase in fos was associated with Morphine ICSA within the NAc, striatum, limbic cortices, amygdala, hippocampus, lateral mammillary nucleus, and the ventral posteromedial thalamus where high levels of fos were expressed exclusively in self-administering WT and DOR-/- mice. Abolition of morphine reward in MOR-/- mice was associated with a decrease in fos positive neurons in the mesocorticolimbic DA system, amygdala, hippocampus (CA1), lateral mammillary nucleus, and a complete absence within the ventral posteromedial thalamus. David et al. [21] concluded that (a) ventral posteromedial thalamus MORs, but not DORs, are critical for morphine reward and (b) the role of VTA-thalamic projections in opiate reward warrants further exploration.

Moreover, clinical and laboratory studies have indicated that the MOR gene contributes to inheritable vulnerability to the development of opiate addiction. Polymorphisms that occur naturally have been identified in the MOR gene. Substitutions occur at high allelic frequencies (10.5 and 6.6\%) in two coding regions single nucleotide polymorphisms (SNPs), the A118G and C17T respectively, of the MOR gene. These SNPs cause amino acid changes in the receptor that impact on an individual's response to opioids and can influence increases or decreases in vulnerability to opiate addiction [22]. Thus, in response to beta-endorphin in cellular assays, the A118G substitution encodes a variant receptor with differences in binding and signal transduction [22]. Finally, to firmly establish the role of MOR in reward and response to buprenorphine, Ide et al. [23] assessed buprenorphine anti- nociception by hot-plate and tail-flick tests, and found that it was significantly reduced in heterozygous mu-opioid receptor knockout (MOR-KO) mice and abolished in homozygous MOR-KO mice. Buprenorphine, on the other hand, was able to establish a conditioned place preference in homozygous MOR-KO, although as the number of copies of wild-type muopioid receptor genes was reduced, the magnitude of place preference was reduced. This study revealed that mu-opioid receptors mediate most of analgesic properties of buprenorphine [23]. We are proposing that to determine patient addiction liability, genetic testing should be incorporated into the beginning of Occupational Medical Clinic programs to reduce iatrogenic opioid prescription addiction, and should include both opioid and dopaminergic risk alleles.

\section{Explanation of Single Nucleotide Polymorphisms}

RDS-associated SNPs can be identified by any suitable method, including DNA sequencing of patients diagnosed with one or more RDS behaviors. After validation, newly identified RDS-associated SNPs can be used in the test. As will be appreciated, once identified and validated, the presence, if any, of one or more RDS-associated SNPs in the nucleic acids derived from a biological sample taken from a patient can be determined using any suitable now known or later-developed assay, including those that rely on site-specific hybridization, restriction enzyme analysis, or DNA sequencing. Table 2 lists a number of particularly preferred RDS-associated SNPs, whereby, the detection of which can be used for the GARS test.

\section{Serotonin (5-Hydroxytriptamine5-HT) Genes (2AReceptor1438G/a)}

Serotonin, also known as 5-hydroxytryptamine or 5-HT, is a neurotransmitter and peripheral NH2 signal mediator that was discovered in the late 1940s. By the early 1950s, neurotransmitter function was identified in the central nervous system of animals. In the late $1950 \mathrm{~s}$, there was evidence for 5-HT receptor peripheral heterogeneity, and by $1979,5-\mathrm{HT}$ binding sites were identified in the brain: 5-HT1 and 5-HT2. 5-HT 2A receptor (5-HT2A) is one of several proteins to which 5-HT binds when brain cells communicate. 5-HT receptors located on the membranes of nerve and other cell types mediate the effects of 5-HT as the endogenous ligand. 5-HT receptors are heptahelical; G protein coupled seven trans-membrane receptors, activated by an intracellular second messenger cascade except for the 5-HT3 receptor, a ligand gated ion channel. The 5-HT receptor contains 471 amino acids in rats, mice, and humans and is widely distributed in peripheral and central tissues. 5-HT receptors mediate contractile responses in a 
Table 2 RDS-associated SNPs

\begin{tabular}{|c|c|c|}
\hline Gene & Risk allele & Comment \\
\hline Dopamine D1 (DRD) & $48 \mathrm{~A}$ & G normal \\
\hline Dopamine D2 (DRD2) & A1 & A2 normal \\
\hline Dopamine D3 (DRD3) & $\mathrm{C}$ & T normal \\
\hline Dopamine D4 (DRD4) & $7 \mathrm{R}$ & 4R normal \\
\hline Dopamine Transporter (DAT1) & $\begin{array}{l}9 \mathrm{R}=\text { Fast uptake } \\
10 \mathrm{R}=\text { slow uptake }\end{array}$ & $\begin{array}{l}\text { Fast DAT could result in hypodopaminergic and slow could result in hyper } \\
\text { dopaminergic }\end{array}$ \\
\hline Serotonin Transporter (5HTTLLR) & $\mathrm{S}$ & Count S not L \\
\hline Catechol-O-methyl-transferase (COMT) & G & $\begin{array}{l}\text { The } \mathrm{G} \text { allele }=\text { Val substation that cause the enzyme COMT which breaks } \\
\text { down Dopamine in the synapse too fast. This could also lead to } \\
\text { hypodopaminergic trait. The } \mathrm{A}=\text { Met = normal }\end{array}$ \\
\hline Mu opiate receptor (OPRM1) & G & $\begin{array}{l}\text { The } \mathrm{G} \text { allele whereby } \mathrm{G}=\mathrm{ASP} \text { this contributes to addiction to opiates and } \\
\text { alcohol. } \mathrm{A}=\mathrm{ASN} \text { normal. Another name is MOR-Mu opiate receptor }\end{array}$ \\
\hline GABA A receptor subunit (GABRA3) & 181 & $\begin{array}{l}\text { This } 181 \text { snp reduces the sensitivity of the GABA receptor and as such } \\
\text { increases the chance for alcoholism and other drugs of abuse. It increases } \\
\text { risk for stress induction, which can also cause relapse }\end{array}$ \\
\hline MAOA uVNTR & $\begin{array}{l}4 \mathrm{R}=\text { Fast uptake } \\
3 \mathrm{R}=\text { slow uptake }\end{array}$ & $\begin{array}{l}\text { This is the strange gene. It sits on the mitochondria in the neuron. MAO is } \\
\text { involved in the breakdown of dopamine and serotonin. The } 4 \mathrm{R} \text { increases } \\
\text { the breakdown and } 3 \mathrm{R} \text { slows the breakdown. Since the gene sits on the } \mathrm{X} \\
\text { chromosome not the } \mathrm{Y} \text { chromosome females are XX and males are XY. } \\
\text { This means that females have two alleles to count and males only have one }\end{array}$ \\
\hline Serotonin 5HTA2 Receptor & $\mathrm{C}$ & $\begin{array}{l}\text { Alcohol dependent }(\mathrm{AD}) \text { patients homozygous for } \mathrm{C} \text { allele had significantly } \\
\text { lower age at onset of alcohol problems than subjects having at least one } \mathrm{T} \\
\text { allele. The results suggest a potential role of the T102C HTR2A } \\
\text { polymorphism in development of alcohol dependence }\end{array}$ \\
\hline Serotonin 5HTA2 Receptor & 1438A allele & $\begin{array}{l}\text { Another polymorphism the } 5 \text {-HT }(2 \mathrm{~A})-1438 \mathrm{~A} \text { allele was significantly more } \\
\text { common in patients than controls }[0.55 \text { and } 0.45 \text {, respectively; corrected } \\
P=0.042, \mathrm{OR}=1.51(95 \% \mathrm{CI}=1.13-2.03)]\end{array}$ \\
\hline
\end{tabular}

series of vascular smooth muscle preparations. In addition, platelet aggregation and increased capillary permeability following exposure to 5-HT have been linked to 5-HT receptormediated functions. Centrally, these receptors are located principally on cells in the cerebral cortex, claustrum, and basal ganglia. 5-HT receptors reduce cyclic adenosine monophosphate (cAMP) and modify the activity and release of other neurotransmitters like glutamate, enkephalin, DA, and GABA. 5-HT2A receptors increase glutamate activity of in many areas of the brain, some of the other 5-HT receptors have the effect of suppressing glutamate. The therapeutic actions that result from increased stimulation of 5-HT receptors in anti-depressant and anxiolytic treatments seems to be opposed by increased stimulation of the 5-HT2A receptors.

\section{Serotonin Receptors (2A) Genetics}

Everyone inherits two copies of the 5-HT2A receptor gene, one from each parent. Small differences in the chemical sequence results, in some people having an adenine (A), switched at the same point for a guanine $(\mathrm{G})$. So a subject can have gene types AA, AG, or GG. According to the US
Department of Health and Human Services National Institutes of Health, "whether depressed patients will respond to an antidepressant depends in part, on which version of a gene they inherit." The chance of a positive response to an antidepressant increase by up to $18 \%$ in those who have two copies of one version of a gene that codes for a component of brain mood-regulation. It is well known that polymorphisms at the 5-HT2A receptor gene vary in terms of frequency, for example, Whites have six times more of the minor allelic version compared to Blacks. These and other findings add to evidence that the component is a receptor for chemical antidepressant action. Serotonergic genes have been also associated with suicide ideation, trauma in children, and criminality [24, 25].

Specifically related to chemical dependencies, these particular genes have been associated with heroin dependence. The 5-HT2A-1438A allele was significantly more common in heroin dependent patients than controls [0.55 and 0.45 , respectively; corrected $P=0.042]$. An interaction between A-1438G of 5-HT2A and 5-HTT polymorphisms was observed, in the presence of short 5-HTTLPR alleles and 12repeat 5-HTT VNTR the association between heroin dependence and the $-1438 \mathrm{AA}$ vs. AG/GG genotypes was enhanced [24.8 \% in heroin-dependent patients vs. $12.6 \%$ in controls; 
corrected $P=0.045]$ [26]. Moreover, genetic analyses showed that the frequency of $102 \mathrm{C}$ allele and $\mathrm{C} 102 \mathrm{C}$ genotype in alcoholic subjects was significantly higher than in controls. In addition, alcoholic patients homozygous for $\mathrm{C}$ allele had alcoholic problems at significantly earlier age of onset than subjects having at least one $\mathrm{T}$ allele. These results point to the possibility of a role for the T102C HTR2A polymorphism in development of alcohol dependence and even relapse [27, 28]. Additionally, 5-HT2A, and 5-HT2C receptors that innervate the DA meso-accumbens pathway may play a prominent role in the behavioral effects of cocaine [29]. Smoking behavior is influenced by genetic factors affecting the dopaminergic system, and dopaminergic polymorphisms have been linked to smoking habits [30]. Since this T102C polymorphism of the 5-HT2A receptor gene modulates the mesolimbic DA system and is associated with reduced receptor gene expression, the purpose of one study [31] was to investigate the relationship it has to tobacco use. The T102C polymorphism was found to be associated with maintenance, but not with the initiation of the smoking habit. The CC genotype was more frequent in current smokers than in never- or former-smokers (chi2 $=$ $6.825, P=0.03$ ) with an odds ratio of $1.63,95 \%$ CI $1.06-$ 2.51. Interestingly, Nichols et al. [32] found that the gene response to LSD was quite dynamic. The expression of some genes increased rapidly and decreased rapidly while other genes changed more gradually. Dose-response studies showed two classes: (1) gene expression maximally stimulated at lower doses, and (2) gene expression that continued to rise at the higher doses. In a series of experiments that used receptor specific antagonists, the role of the 5-HT1A and 5HT2A receptors in mediating the increases in gene expression, was examined and found that the 5-HT2A receptor activation was responsible for the majority of expression increases.

\section{5-HTTLPR (Serotonin Transporter-Linked Polymorphic Region)}

The human 5-HT transporter is encoded by the SLC6A4 gene on chromosome 17q11.1-q12. This is the site for cellular reuptake of 5-HT and a site where many drugs with central nervous system effects are activated. They include therapeutic agents like antidepressants and psychoactive drugs of abuse like cocaine. The 5-HT transporter has a prominent role in the metabolic cycle of many antidepressants, antipsychotics, anxiolytics, anti-emetics, and anti-migraine drugs. Higher expression of brain 5-HTT is associated with the (long allele) insertion variant compared to the (short allele) deletion variant. The results of some studies show that long allele is responsible for increased 5HT transporter mRNA transcription in human cell lines. Further, this may be due to the Aallele of rs25531, so that subjects with the long-rs25531 (A) allelic combination (LA) have higher levels, with the long-
rs25531(G) earners have levels more similar to short-allele carriers. Saiz et al. [26] found an excess of -1438G and 5HTTLPR L carriers in alcoholic patients in comparison to the heroin dependent group, the polymorphisms A-1438G and 5HTTLPR also distinguished, alcohol from heroin dependent patients. The association of $-1438 \mathrm{~A} / \mathrm{G}$ was especially pronounced with alcohol dependence when 5-HTTLPR S/S was present, less evident with 5-HTTLPR L/S, and not present with 5-HTTLPR.

The 5-HT transporter, encoded by the SLC6A4 gene, influences the synaptic actions of 5-HT and is responsive to stress hormones. In fact, the risk for suicidal behavior in CT exposed individuals is independently affected by the $5^{\prime}$ and $3^{\prime}$ SLC6A4 functional variants [25]. National Longitudinal Study of Adolescent Health data shows that there is a significant gene-environment correlation between 5-HTTLPR and neglect for females only. Findings also reveal that 5-HTTLPR is associated with an increased risk of neglect for females and neglected females' risk of abusing marijuana [33]. Socialization scores were significantly lower in males (greater sociopathy), with the $\mathrm{L}^{\prime} \mathrm{L}^{\prime}$ genotype (i.e., those homozygous for the $\mathrm{L}(\mathrm{A})$ allele) than males who carried the $\mathrm{S}^{\prime}$ allele $(P=$ $0.03)$. In contrast, women with the $S^{\prime} S^{\prime}$ genotype tended to have a lower Socialization Index on the California Psychological Inventory than women with one copy of the $L^{\prime}$ allele $(P=0.07)$ and lower socialization scores than women with two $\mathrm{L}^{\prime}$ alleles $(P=0.002)$. The tri-allelic 5 -HTTLPR polymorphism had opposite effects on socialization scores in men than women with alcohol use disorders [34].

The genotype coding for low 5-HTT expression is associated with a better opioid analgesic effect, while the 5-HTTLPR sallele has been associated with higher risk of developing chronic pain conditions. Downregulation of 5-HT1 receptors has been associated with the s-allele, and Kosek et al. [35] have suggested that individuals have an increased analgesic response to opioids during acute pain stimuli with a desensitization of 5HT1 receptors, but may still be at increased risk of developing chronic pain conditions. The risk of alcohol dependence and co-occurring clinical features is increased in the presence of the short (S) allele of the 5-HT transporter gene promoter polymorphism (5-HTTLPR). While no other factor that were measured played a significant role, the $\mathrm{S}$ allele was significantly associated with relapse $(P=0.008)$. Thus, in abstinent alcoholdependent patients the risk of relapse may be influenced by $\mathrm{S}$ allele of the 5-HTTLPR polymorphism, possibly through intermediate phenotypes [36].

\section{Catecholamine-O-Methyltransferase (COMT) Val158Met Polymorphism}

Catechol- $O$-methyltransferase (COMT) was discovered in 1957 by the Nobel Prize Winner biochemist Julius Axelrod. 
COMT is an extra cellular enzyme that breaks down DA, adrenaline, and noradrenaline in the synapse. COMT is involved in the metabolism of the catecholamine neurotransmitters (DA, epinephrine, and norepinephrine). The enzyme introduces a methyl group donated by $S A$-denosyl-methionine to the catecholamine. Any compound having a catechol structure, like catechol-estrogens and catechol-containing flavonoids, are substrates of COMT, for example, L-dopa, a precursor of catecholamines and an important substrate of COMT. Variability of the COMT activity has previously been associated with the Val158Met polymorphism of the COMT gene and alcoholism. Serý et al. [37] found an association between alcoholism in male subjects and the Val158Met polymorphism of the COMT gene. Serý et al. also found the significant difference between allele and genotype frequencies of male alcoholics and male controls. In one of the subjects genotyped with heroin addiction, carries of the DRD2 A1 allele, also carried the low enzyme COMT activity genotype (A/A). This is in agreement with the work of Cao et al. [38] in 2003 who found no association with the high $\mathrm{G} / \mathrm{G}$ and heroin addiction. No significant differences in genotype and allele frequencies of $108 \mathrm{val} /$ met polymorphism of COMT gene were observed between heroin-dependent subjects and normal controls. No differences in genotype and allele frequencies of $900 \mathrm{Ins}$ C/Del C polymorphism of COMT gene were observed between heroin-dependent subjects and normal controls. While there is still some controversy regarding the COMT association with heroin addiction, it was also interesting that the $\mathrm{A}$ allele of the val/met polymorphisms ( $-287 \mathrm{~A} / \mathrm{G}$ ) found by Cao et al. [38] was found to be much higher in heroin addicts than controls. Faster metabolism results in reduced DA availability at the synapse, which reduces postsynaptic activation, inducing hypodopaminergic functioning. Generally, Vandenbergh et al. [39] in 1997, and others [40] supported an association with the Val allele and Substance Use Disorder, but others did not [41]. Li et al. [42] found the COMT rs737866 gene variants were independently associated with both novelty seeking (NS) and age of onset of drug use. Those subjects with the TT genotype had higher NS subscale scores and an earlier onset age of heroin use than individuals with CT or CC genotypes. In a multivariate analysis, the inclusion of the NS sub score variable weakened the relationship between the COMT rs737866 TT genotype and an earlier age of onset of drug use. Li's findings that COMT is associated with both NS personality traits and with the age of onset of heroin use helps to clarify the complex relationship between genetic and psychological factors in the development of substance abuse. Case-control analyses did not show any significant difference in allele or genotype distributions. However, a dimensional approach revealed a significant association between the COMT-Val (158) Met and NS. Both controls and opiate users with Met/Met genotypes showed higher NS scores compared to those with the Val allele. Demetrovics et al. [43] reported the NS scores also were significantly higher among opiate users; however, no interaction was found between group status and COMT genotype. A functional single nucleotide polymorphism (a common normal variant) of the gene for COMT has been shown to affect cognitive tasks broadly related to executive function, such asset shifting, response inhibition, abstract thought, and the acquisition of rule sorting structure. This polymorphism in the COMT gene results in the substitution of the amino acid valine for methionine. It has been shown that this valine variant catabolizes DA at up to four times the rate of its methionine counterpart resulting in a significant reduction of synaptic DA following neurotransmitter release, ultimately reducing dopaminergic stimulation of the post-synaptic neuron [44] another driver in the GARS.

\section{Monoamine Oxidase-A}

Monoamine oxidase-A (MAOA) is an enzyme that degrades the neurotransmitters 5-HT, norepinephrine, and DA in the mitochondria. MAOA is involved with both physical and psychological functioning and classified as a flavoprotein since it contains the covalently bonded cofactor FAD. MAOA is an oxidative catalyst that uses oxygen to deaminate-remove an amine group from molecules, resulting in the corresponding aldehyde and ammonia.

Both forms of MOA (A and B) enzymes are substrates for the activity of a number of monoamine oxidase inhibitor drugs and are, therefore, well known in pharmacology. They are particularly important in the catabolism of monoamines ingested in food and vital to the inactivation of monoaminergic neurotransmitters. They display different specificities MAO-A primarily breaks down serotonin, melatonin, norepinephrine, and epinephrine while phenylalanine and benzyl amine are mainly broken down by MAO-B. Both forms break down DA, tyramine and tryptamine equally.

The gene that encodes MAOA is found on the X chromosome is located $1.2 \mathrm{~kb}$ upstream of the MAOA coding sequences and contains a polymorphism (MAOA-uVNTR) [45]. The MAOA-uVNTR consists of a 30-base pair repeated sequence, six allele variants containing either 2-, 3-, 3.5-, 4-, 5-, or 6-repeat copies [46]. Functional studies have indicated the alleles confer variations in transcriptional efficiency, for example, the 3.5- and 4-repeat alleles result in higher efficiency, whereas, the 3-repeat variant conveys lower efficiency [47]. To date, there are fewer consensuses regarding the transcriptional efficiency of the other less commonly occurring alleles, for example, 2-, 5-, and 6-repeat. The MAOA gene is a highly plausible candidate for effecting differences in the manifestation of psychological traits and psychiatric disorders based on its primary role in regulating monoamine turnover, and thereby influencing levels of norepinephrine, DA, and 5HT [48]. Levels of MAO-A in the brain of patients with major 
depressive disorder, measured using positron emission tomography (PET), are elevated by an average of $34 \%$. Recently, evidence has indicated that the MAOA gene may associate with depression [49] and stress [50]. Evidence regarding whether lower or higher transcriptional efficiency of the MAOA gene, is positively associated with psychological pathology, has however, been mixed. The MAOA-uVNTR polymorphism low-activity 3-repeat allele has been positively related to symptoms of cluster B personality disorders and antisocial personality [51]. Other studies suggest that unhealthy psychological characteristics such as trait aggressiveness and impulsivity are related to alleles associated with higher transcriptional efficiency. Low MAO activity and the neurotransmitter DA are both important factors in the development of alcohol dependence. Huang et al. [52] investigated whether the association between the DRD2 gene and alcoholism is affected by different polymorphisms of the MAO type A $(M A O A)$ gene since MAO is an important enzyme associated with the metabolism of biogenic amines. They found that the genetic variant of the DRD2 gene associated with the anxiety, depression (ANX/DEP) alcoholic phenotype, and the genetic variant of the MAOA gene was associated with alcoholism. Specifically, subjects carrying the MAOA 3repeat allele and genotype A1/A1 of the DRD2 were 3.48 times more likely to be ANX/DEP alcoholics than the subjects carrying the MAOA 3-repeat allele and DRD2 A2/A2 genotype. Thus, the MAOA gene may modify the association between the DRD2 gene and ANX/DEP alcoholic phenotype. Overall, Vanyukov et al. [53] suggested that, although not definitive, variants in MAOA account for a small portion of the variance of risk for Substance Use Disorder, possibly mediated by liability to early onset behavioral problems.

\section{Dopamine D1 Receptor Gene}

The DA receptor D1, also known as DRD1 a subtype of the DA receptor is a protein encoded by the DRD1 gene and the most abundant DA receptor in the human central nervous system where it expresses primarily in the caudate putamen. This G-protein-coupled receptor activates cyclic AMPdependent protein kinases and stimulates adenylyl cyclase. D1 receptors regulate neuronal growth and development, modulate DA D2 receptor-mediated events and mediate some behavioral responses. There are two transcript variants of the DRD1 gene that are initiated at alternate transcription sites.

The DA D1 receptor has been associated with many brain functions that include, motor control, inattentive symptoms, and reward and reinforcement mechanisms. Betel et al. [54] found that the DRD1 gene polymorphism T allele of the rs686 was significantly $(P=0.0008)$ more frequent in patients with alcohol dependence. Frequency increased with severe dependence and was even higher for patients with severe complications like withdrawal seizures. Alcohol dependence was significantly, more precisely associated with a specific haplotype $\mathrm{rs} 686^{*} \mathrm{~T}-\mathrm{rs} 4532 * \mathrm{G}$ within the $\mathrm{DRD} 1$ gene. In another study, Kim et al. [55] found that the severity of the alcohol-related problem as measured by the Alcohol Use Disorders Identification Test in a gene dose-dependent manner, was significantly associated with one $5^{\prime}$ UTR polymorphism in the DRD1 (DRD1-48A $>$ G) gene; $24.37( \pm 8.19)$ among patients with $-48 \mathrm{~A} / \mathrm{A}$ genotype, $22.37( \pm 9.49)$ among those with $-48 \mathrm{~A} / \mathrm{G}$ genotype, and $17.38( \pm 8.28)$ among those with $-48 \mathrm{G} / \mathrm{G}$ genotype $(P=0.002)$. Novelty seeking, harm avoidance and persistence were also found to be associated with the DRD1-48A >A genotype. Most recently, Peng et al. [56] indicated that DRD1 gene polymorphism may be associated with the rapid acquisition of heroin dependence, from first drug use but may not play an important role in the susceptibility to heroin dependence in the Chinese Han population. Others have also found significant associations with opiate abuse relative to controls [57]. DRD1 antagonists may indeed reduce the acquisition of cocaine-cue associations and cocaine-seeking behavior. Genetic association studies revealed that polymorphisms of the DRD1 gene significantly associated with nicotine dependence [58]. Ni et al. [59] found a significant association between DRD1 and bipolar disorder for haplotype TDT analysis. Thus, these results suggest DRD1 may play a role in the etiology of bipolar disorder.

\section{Dopamine D2 Receptor Gene (DRD2)}

DA receptor $\mathrm{D}_{2}$, also known as $\mathrm{DRD} 2$, is a protein that is encoded by the $D R D 2$ gene which encodes the $\mathrm{D}_{2}$ subtype of the DA receptor in humans. This G protein-coupled receptor inhibits adenyl cyclase activity. Two transcript variants encode different isoforms and a third variant that has been described are the result of alternative splicing of the gene. In mice, of $\mathrm{D} 2 \mathrm{R}$ surface expression is regulated in the dentate gyrus by the calcium sensor NCS-1 and controls exploration, synaptic plasticity, and memory formation.

DA has the chemical formula $\left(\mathrm{C}_{6} \mathrm{H}_{3}(\mathrm{OH})_{2}-\mathrm{CH}_{2}-\mathrm{CH}_{2}-\right.$ $\mathrm{NH}_{2}$ ) is a member of the catecholamine family. DA is a precursor to the chemical messengers' epinephrine (adrenaline) and norepinephrine (noradrenaline). Arvid Carlsson won a share of the 2000 Nobel Prize in Physiology and Medicine for showing that DA is not just a precursor to these substances, but is also a neurotransmitter.

Older antipsychotic drugs, like haloperidol and chlorpromazine are DRD2 antagonists, however they are exceedingly nonselective, being selective for the "D2-like family" receptors; binding to D2, D3, and D4 and many other receptors, such as, those for 5-HT and histamine. This lack of selectivity makes them difficult to research and results in a range of side effects. Similarly, older DA agonists like bromocriptine and 
cabergoline used to treat Parkinson's disease are also poorly selective. However, the number of selective D2 ligands available for scientific research is likely to increase.

Almost a decade before Carlsson and others were awarded the Nobel Prize the DA D2 receptor gene (DRD2) was first associated with severe alcoholism and is today the most widely studied gene in psychiatric genetics [7]. The Taq1 A is a SNP (rs: 1800497) originally thought to be located in the 3 '-untranslated region of the DRD2 but has since been shown to be located within exon 8 of an adjacent gene, the ankyrin repeat and kinase domain containing 1 (ANKK1). Importantly, while there may be distinct differences in function, the miss-location of the Taq1A allele may be attributable to the ANKKI and the DRD2 being on the same haplotype or the ANKKI being involved in reward processing through a signal transduction pathway [60]. The ANKKI and the DRD2 gene polymorphisms may have distinct and different actions with regard to brain function [61]. Presence of the $\mathrm{Al}^{+}$genotype (A1/A1, A1/A2) compared to the $\mathrm{A}^{-}$genotype (A2/A2) is associated with reduced receptor density [62-64]. This reduction causes hypodopaminergic functioning in the DA reward pathway. Other DRD2 polymorphisms such as the C (57T, A SNP (rs: 6277)) at exon 7 also associates with a number of RDS behaviors including drug use [65]. Compared to the $\mathrm{T}^{-}$genotype $(\mathrm{C} / \mathrm{C})$, the $\mathrm{T}^{+}$genotype $(\mathrm{T} / \mathrm{T}, \mathrm{T} / \mathrm{C})$ is associated with reduced translation of DRD2 mRNA and diminished DRD2 mRNA, leading to reduced DRD2 density and a predisposition to alcohol dependence [66]. The Taq 1 A allele is a predictive risk allele in families [67].

More recently, Kraschewski and colleagues [68] found the DRD2 haplotypes I-C-G-A2 and I-C-A-A1 to occur with a higher frequency in alcoholics. The rare haplotype I-C-A-A2 occurred less often in alcoholics and was less often transmitted from parents to their affected children (1 vs. 7). Among the subgroups, I-C-G-A2 and I-C-A-A1 had a higher frequency in Cloninger 1 alcoholics and alcoholics with a positive family history. Cloninger 2 alcoholics had a higher frequency of the rare haplotype D-T-A-A2 as compared with controls. In patients with a positive family history, haplotype I-C-A-A2 and Cloninger 1 alcoholics, haplotype I-T-A-A1 was less often present, confirming that haplotypes, which are supposed to induce a low DRD2 expression, were associated with alcohol dependence. Furthermore, supposedly highexpressing haplotypes weakened or neutralized the action of low-expressing haplotypes [68]. Moreover, Kazantseva et al. [69] found, significant effects of the ANKK1/DRD2 Taq1A on "Neuroticism" and of SLC6A3 rs27072 on "Persistence" in both genders. The association between ANKK1/DRD2 Taq1A A2/A2-genotype and higher Novelty Seeking and lower Reward Dependence was shown in men but not in women.

\section{Dopamine D3 Receptor Gene}

The DA D3 receptor is a protein that is encoded by the DRD3 gene in humans and is a subtype of the DA receptor which inhibits adenylyl cyclase through inhibitory G-proteins. This receptor is expressed in older regions of the brain phylogenetically. This suggests that it is important in emotional functions. It is a target for drugs that treat Parkinson's disease, schizophrenia, and drug addiction. Differently encoded isoforms from alternative gene splicing result in transcription of multiple variants. Some of these variants may be subject to nonsense-mediated decay, however, in rodent models of depression D3 agonists like pramipexole, rotigotine, and 7-OH DPAT, among others, display antidepressant effects.

Data from Vengeliene et al. [70] revealed an up-regulation of the DA D3 receptor (D3R) in the striatum after 1 year of voluntary alcohol consumption of alcohol preferring rats that was confirmed by qRT-polymerase chain reaction. This finding was further supported by up-regulation of striatal D3R mRNA found in non-selected Wistar rats, after long-term alcohol consumption when compared with age-matched control animals. Moreover, they examined the role of the D3R in mediating alcohol relapse behavior. They used the alcoholdeprivation-effect model, in long-term alcohol drinking Wistar rats and the model of cue-induced reinstatement of alcohol-seeking behavior, using the selective D3R antagonist SB-277011-A (0, 1, 3, and $10 \mathrm{mg} / \mathrm{kg})$ and the partial agonist BP $897(0,0.1,1$, and $3 \mathrm{mg} / \mathrm{kg})$. Both treatments caused a dose-dependent reduction of relapse-like drinking in the alcohol-deprivation-effect model, as well as a decrease in cue-induced ethanol-seeking behavior. They concluded that long-term alcohol consumption led to an up-regulation of the DA D3R that might have contributed to alcohol-seeking and relapse. Moreover, the Gly9, Gly9 genotype of the DRD3 Ser9Gly polymorphism was associated with increased rates of obsessive personality disorder symptomatology [71].

Furthermore, several lines of evidence indicate that dopaminergic neurotransmission is involved in the regulation of impulsive aggression and violence and that genetically determined variability in dopaminergic gene expression modifies complex traits including that of impulsivity and aggression. In one study, Retz et al. [72] reported an association of the DRD3 polymorphism with impulsiveness according to Eysenck's EIQ and scores on the German short version of the Wender Utah Rating Scale (WURS-k), which they used for the assessment of a history of attention deficit hyperactivity disorder (ADHD) symptoms. This association was detected in a group of violent offenders, but not in non-violent individuals. Highest scores of EIQ impulsiveness and the WURS-k were found in heterozygous violent individuals while homozygotes showed significant lower rating scores, suggesting a heterosis effect. The results of their study suggest that variations of the DRD3 gene are likely involved in the regulation of 
impulsivity and some psychopathological aspects of ADHD related to violent behavior.

Finally, as opiates increase DA transmission, Spangler et al. [73] measured the effects of morphine on DA-related genes using a real-time optic PCR assay that reliably detects small differences in mRNA in discrete brain regions. As reported previously by others, there was no alteration in D1R mRNA and a $25 \%$ decrease in D2R mRNA in the caudate-putamen, $2 \mathrm{~h}$ after the final morphine injection. Importantly, in the same RNA extracts, D3R mRNA showed significant increases of $85 \%$ in the caudate-putamen and $165 \%$ in the ventral midbrain, including the substantia nigra and VTA. There were no other significant morphine effects. The understanding of the ability of D3R agonists to reduce the effects of morphine was extended by the finding that chronic intermittent injections of morphine caused an increase in D3R mRNA extends.

\section{Dopamine D4 Receptor Gene}

The DA receptor D4 is encoded by the DRD4 gene on chromosome 11 located in $11 \mathrm{p} 15.5$ in humans. Like the DRD2 the D4 receptor is a G protein-coupled receptor, activated by the neurotransmitter DA. It also inhibits the adenylate cyclase enzyme which reduces the intracellular second messenger cyclic AMP concentration. The DRD4 has been associated with numerous psychiatric and neurological conditions including addictive behaviors, and eating disorders (like binge-eating anorexia and bulimia nervosa, bipolar disorder) schizophrenia and Parkinson's disease. Slight variations (mutations/polymorphisms) in the human DRD4 gene include: A 48-base pair VNTR in exon 3; 13-base pair deletion of bases 235 to 247 in exon 1; C-521T in the promoter; Val194gLY; 12 base pair repeat in exon I; A polymorphic tandem duplication of $120 \mathrm{bp}$. These mutations have been associated with a number of behavioral phenotypes, including autonomic nervous system dysfunction, ADHD, schizophrenia, and the personality trait of novelty seeking. Specifically, the 48-base pair VNTR in exon 3 ranges from 2 to 11 repeats. Polymorphisms with 6 to 10 repeats are the "Long" versions of the alleles. The frequency of the alleles varies considerably between populations, for example, the incidence of the 7-repeat version is high in America and low in Asia. The DRD4 long variant, or more specifically the 7 repeat $(7 \mathrm{R})$, has been loosely linked to psychological traits and disorders like susceptibility for developing ADHD appears to react less strongly to DA molecules. The 7R allele appears to have been selected about 40,000 years ago then in 1999, Chen et al. [74, 75] showed that nomadic populations had higher frequencies of $7 \mathrm{R}$ alleles than sedentary ones. They also observed that higher frequency of $7 \mathrm{R} /$ long alleles in populations who migrated further from 1,000 to 30,000 years ago. Recently, it was found that Ariaals with the $7 \mathrm{R}$ alleles, who are newly sedentary (non-nomadic), are not as healthy as nomadic Ariaal men with $7 \mathrm{R}$ alleles [76].

Despite early findings of an association between the DRD4 48 bp VNTR and novelty seeking (characteristic of exploratory and excitable people), a 2008 meta-analysis compared 36 published studies of novelty seeking and the polymorphism and found no effect. The meta-analysis of 11 studies did find that another polymorphism in the gene, the $-521 \mathrm{C} / \mathrm{T}$, showed an association with novelty seeking [77]. In any case, novelty-seeking behavior probably is mediated by several genes, and the variance attributable to DRD4 by itself is not particularly large.

Several studies have suggested that parenting may affect the cognitive development of children with the 7-repeat allele of DRD4 [78]. Parenting that has maternal sensitivity, mindfulness, and autonomy-support at 15 months was found to alter children's executive functions at 18 to 20 months [78]. Children with poorer quality parenting were more impulsive and sensation seeking than those with higher quality parenting [78]. Higher quality parenting was associated with better effortful control in 4-year-olds [78] and these effects are impacted by epigenetic markers on chromatin structures.

There is evidence that the length of the D4 DA receptor (DRD4) exon 3 variable number of tandem repeats (VNTR) affects DRD4 functioning by modulating the expression and efficiency of maturation of the receptor [79]. The 7R VNTR requires significantly higher amounts of DA to produce a response of the same magnitude as other size VNTRs [80], and this reduced sensitivity or DA resistance leads to hypodopaminergic functioning. Thus, 7R VNTR has been associated with substance-seeking behaviors [81, 82]. However, not all reports support this association. Biederman et al. [83] evaluating a number of putative risk alleles using survival analysis, revealed that by 25 years of age, $76 \%$ of subjects with a DRD4 7R allele were estimated to have significantly more persistent ADHD compared with $66 \%$ of subjects without the risk allele. In contrast, there were no significant associations between the course of ADHD and the DAT1 10repeat allele and 5HTTLPR long allele. These findings suggested that the DRD4 7R allele, is associated with increased persistence in the course of ADHD. Moreover, Grzywacz et al. [84] evaluated the role of DRD4 exon 3 polymorphisms (48 bp VNTR) in the pathogenesis of alcoholism and found significant differences in the short alleles (2-5 VNTR) frequencies, between controls and patients with a history of delirium tremens and/or alcohol seizures. A trend also was observed in the higher frequency of short alleles amongst individuals with an early age of onset of alcoholism. The results of this study suggest that inherited short variants of DRD4 alleles (3R) may play a role in the pathogenesis of alcohol dependence and carriers of the 4R may have a protective effect for alcoholism risk behaviors. It is of further interest 
that work from Kotler et al. [85] in heroin addicts illustrated that central dopaminergic pathways figure prominently in drug-mediated reinforcement including novelty seeking, suggesting that DA receptors are likely candidates for association with substance abuse. These researchers showed that the $7 R$ allele was significantly over-represented in the opioiddependent cohort and conferred a relative risk of 2.46 .

\section{Dopamine Transporter Gene (DAT1)}

The DA transporter, also known as DA active transporter (DAT, SLC6A3), moves DA the neurotransmitter out of the synapse back into the cytosol via a membrane-spanning protein pump. From there, DA and norepinephrine are sequestered by other transporters into vesicles for later storage and release. DA reuptake through which DA is cleared from synapses primary by the mechanism of the DAT gene, although in the prefrontal cortex, there may be an exception, where evidence points to a larger role for the norepinephrine transporter [86, 87].

DAT is thought to be implicated in a number of DA-related disorders, including ADHD, bipolar disorder, clinical depression, and RDS. The gene that encodes the DAT protein is located on human chromosome 5 , consists of 15 coding exons and is roughly $64 \mathrm{kbp}$ long. Evidence for the associations between DAT- and DA-related disorders has come from a type of genetic polymorphism, known as a VNTR, in the DAT gene (DAT1), which influences the amount of protein expressed. DAT is an integral membrane protein that removes DA from the synaptic cleft and deposits it into surrounding cells, thus terminating the signal of the neurotransmitter. DA underlies several aspects of cognition, including reward, and DAT facilitates regulation of that signal $[88,89]$.

In the model for monoamine transporter function that is most widely accepted, before DA can bind sodium ions must bind to the DAT extracellular domain. Once DA binds to sodium ions change in the conformation of the protein allows both the DA and the sodium to unbind intracellularly [90]. Studies using electrophysiology and radioactive-labeled DA have confirmed that DA is transported across the neuronal membrane with sodium ions. The chlorine ions are required to prevent a buildup of positive charge. These studies have demonstrated that the direction and rate of transport, depends on the sodium gradient [77]. It is known that any resultant activity changes in membrane polarity will profoundly affect transport rates and depolarization will induce DA release [91].

Like the GABA transporter, the brain distribution of DAT is highest in the nigrostriatal, mesocortical, and mesolimbic pathways [92] and gene expression patterns in adult mouse show that expression is high in the substantia nigra pars compacta [93]. It has been confirmed that DAT in the mesocortical pathway was also found in the VTA. DAT is localized in the axon terminals of the striatum and shown experimentally to be co-localized with nigrostriatal terminals, tyrosine, and DA D2 receptors. These results suggest that striatal DA reuptake may occur and DA diffuses into the substantia nigra from the synaptic cleft. It appears that DAT is transported into the dendrites, where it can be found in preand postsynaptic active zones, smooth endoplasmic reticulum, and plasma membrane. These localizations suggest that intracellular and extracellular DA levels of nigral dendrites are modulated by DAT.

\section{Genetics and Regulation}

The gene for DAT is located on chromosome $5 \mathrm{p} 15$, it is confirmed that the protein encoding for the gene is over $64 \mathrm{~kb}$ long and comprises 15 coding segments or exons [94]. The DAT gene has a VNTR at the intron 8 region and another at the $3^{\prime}$ end (rs28363170) [95]. VNTR differences have been shown to influence the basal level of expression of the transporter and associate with RDS behaviors, such as various addictions and other DA-related disorders [96]. Interestingly, Nurri, a nuclear receptor that regulates many DArelated genes, can bind the promoter region of this gene and subsequently induce expression [97]. In addition, the DAT promoter also may be the target of the transcription factor Sp1. Kinases are essential for functional regulation of this protein. The rate at which DAT removes DA from the synapse affecting the quantitative amount of DA in the cell depends upon kinases. Understanding the molecular neurobiology of the DAT gene provides the basis for studies showing hyperactivity, severe cognitive deficits, and motor abnormalities of mice with no DA transporters [98]. Similarities of these effects to the symptoms of ADHD characteristics are striking. Differences in the functional differences, in VNTR, have been identified as risk factors for bipolar disorder [99] and ADHD [100]. Although controversial, data have emerged that suggest there also is an association with stronger alcohol withdrawal symptoms [101, 102]. On the other hand, non-smoking behavior and ease of quitting is associated with an allele of the DAT gene of the with normal protein levels [103]. Additionally, male adolescents in high-risk families, with an absence of maternal affection and a disengaged mother, who carry the 10allele VNTR repeat, associate with a statistically significant affinity for antisocial peers [104]. Increased DAT activity is associated with clinical depression [105]. Decreased DAT levels of expression are associated with aging, and may underlie a mechanism that compensates for decreases in DA release as a person ages [106].

Cocaine reduces the rate of transport, blocking DAT by binding directly to the transporter [107]. In contrast, amphetamines trigger a signal cascade thought to involve PKC or MAPK that leads to the internalization of DAT molecules, 
which are normally expressed on the neuron's surface [108]. Amphetamine on DAT also has a direct effect in the increased levels of secreted DA [109]. Lipophilic AMPH diffuses into the cytoplasm and the DA secretory vesicles disrupting the proton gradient established across the vesicle wall. This induces a leaky channel, and DA diffuses out into the cytoplasm. Additionally, AMPH causes a reversal of normal DA flow at the DAT. Instead of DA reuptake, in the presence of AMPH, a reversal in the mechanism of DAT occurs causing an outflow of DA released into the cytoplasm into the synaptic space changing it from a symporter to an antiporter-like functionality [110-112]. These mechanisms both result in less removal of DA from the synapse, increased signaling, which may underlie the pleasurable feelings elicited by these substances [113].

The DA transporter protein regulates DA-mediated neurotransmission by rapidly accumulating DA that has been released into the synapse [113]. Moreover, within 3 noncoding region of DAT1 lies a VNTR polymorphism [113]. There are two important alleles that may independently increase risk for RDS behaviors. The 9 repeat (9R) VNTR has been shown to influence gene expression and to augment transcription of the DA transporter protein [114]. Therefore, this results in an enhanced clearance of synaptic DA, yielding reduced levels of DA to activate postsynaptic neurons. Presence of the 9R VNTR has been linked to Substance Use Disorder [115], but not consistently [116]. Moreover, in terms of RDS behaviors, Cook et al. [117] was the first group that associated tandem repeats of the DAT gene in the literature. While there have been some inconsistencies associated with the earlier results, the evidence is mounting in favor of the view that the $10 \mathrm{R}$ allele of DAT is associated with high risk for ADHD in children and adults alike. Specifically, it was the nonadditive association for the 10-repeat allele to be significant for hyperactivity-impulsivity symptoms, but exploratory analyses of the non-additive association of the 9-repeat allele of DAT1 with HI and oppositional defiant disorder symptoms also was significant. However, Volkow's [118] group found that 12 months of methylphenidate treatment significantly increased striatal DA transporter availability in ADHD (caudate, putamen, and ventral striatum) by $24 \%$, whereas there were no changes in control subjects retested at the 12-month interval.

\section{Gamma Aminobutyric Acid (GABA) 1519T $>$ CGABA (A)alpha6Gene}

The role of GABA as the primary inhibitory neurotransmitter is the regulation of neuronal excitability throughout human central nervous system. First synthesized in 1883 , as a plant and microbe metabolic product, it was not until 1950 that GABA was found to be an integral to brain functioning and directly responsible for muscle tone regulation [119].

GABA acts at the brains inhibitory synapses where it binds to specific transmembrane receptors. This binding in the plasma membrane of both pre- and postsynaptic neuronal processes opens the ion channels, discovered by Nobel Prize winner Erwin Neher in 1991. Ion channels allow chloride ions which are negatively charged into the cell or potassium ions which are positively charged to flow out of the cell. These actions change the transmembrane potential, causing hypo- or hyperpolarization. Polarization depends on the direction chloride flow. GABA is depolarizing (excitatory) when net chloride flows out of the cell and hyperpolarizing (inhibitory) when the net chloride flows into the cell. It is known that as the brain develops into adulthood the role of GABA changes from excitatory to inhibitory [120].

There are two known classes of GABA receptor: $\mathrm{GABA}_{\mathrm{A}}$ receptor, which is part, of a ligand-gated ion complex, and $\mathrm{GABA}_{\mathrm{B}}$ (G protein-coupled) metabotropic receptors that use intermediaries to open or close ion channels. GABAergic neurons that produce GABA have a mostly inhibitory action at receptors, although some GABAergic neurons, such as chandelier cells are able to excite their glutamatergic receptors or neurons counterparts [120-123].

In the metabolic pathway, called the GABA shunt, the enzyme L-glutamic acid decarboxylase and pyridoxal phosphate, the active form of vitamin B6, is used, as a cofactor, to synthesize GABA in the brain from glutamate, the principal excitatory neurotransmitter. In this process that converts glutamate into GABA [124, 125], the GABA transaminase enzyme catalyzes the conversion of 2-oxoglutarate and 4aminobutanoic acid into glutamate and succinic semialdehyde. Then the enzyme succinic semialdehyde dehydrogenase oxidizes succinic semialdehyde into succinic acid which enters the citric acid cycle as a usable source of energy [126].

Drugs, known as GABA analogues or GABAergic drugs act as allosteric modulators of GABA receptors, to increase the amount of available GABA and usually have, anti-anxiety, anti-convulsive, and relaxing effects $[127,128]$. In general, GABA does not cross the blood-brain barrier [129]. At least one study suggests that blocking GABA increases the amount of DA released [130].

\section{Genetics of GABA Receptor Gene Polymorphisms}

GABA receptor genes have received some attention as candidates for drug use disorders. One reason for this is that the DA and GABA systems are functionally interrelated [112]. Research suggests that DA neurons projecting from the anterior VTA to the NAc are tonically inhibited by GABA through its actions at the GABAA receptor [131]. Moreover, it has been shown that alcohol [132] or opioids [133] enhancement of 
GABAergic (through GABAA receptor) transmission inhibits the release of DA in the mesocorticolimbic system. Thus, a hyperactive GABA system, by inhibiting DA release, could also lead to hypodopaminergic functioning. Because of this, GABA genes are of interest in the search for causes of drug use disorders. A dinucleotide repeat polymorphism of the GABA receptor $\beta 3$ subunit gene (GABRB3) results in either the presence of the 181-bp G1 or 11 other repeats designated as non-G1 (NG1) [134]. Research indicates that the NG1 has an increased prevalence in children of alcoholics [134]. Presence of the NG1 has been associated with alcohol dependence $[135,136]$. In addition, other GABA receptor genes have been associated with this disorder [137]. In fact, craving for alcohol and food has been studied in association with alcohol dependence and eating disorders, respectively. Thus, one subclass of the GABA receptor, 1519T $>$ C GABA (A) alpha 6 has been associated with both ethanol dependence and weight gain. This gene polymorphism has been associated with hypo-cortisolism and perhaps abdominal obesity. Interestingly, the pathophysiology may involve various epigenetic factors, such as stress that destabilize the GABAhypothalamic-pituitary adrenal systems in those with genetic vulnerability. In T-allele carriers, the change in craving for alcohol during treatment for alcohol dependence is negatively associated with changes in craving for food as well [137].

Expression patterns of GABAergic genes in rodent brains have been elucidated but not in humans. There are many GABAergic pathways and factor analysis involving global expression on 21 of these pathways has been performed. Specifically, postmortem data from hippocampus of eight alcoholics, eight cocaine addicts, and eight controls was evaluated to determine factor specificity for response to chronic alcohol/cocaine exposure. While RNA-Seq six gene expression factors were identified and loaded onto two factors, most genes loaded $(\geq 0.5)$ onto one factor. These analyses led to the understanding that the chromosome 5 gene cluster was the largest factor ( 0.30 variance) and as such encodes the most common GABAA receptor, $\alpha 1 \beta 2 \gamma 2$, and genes encoding the $\alpha 3 \beta 3 \gamma 2$ receptor. Interestingly, within this factor, these genes were unresponsive to chronic alcohol/cocaine exposure. However, chronic alcohol/cocaine exposure affected chromosome 4 gene-cluster factor ( 0.14 variance) that encoded the $\alpha 2 \beta 1 \gamma 1$ receptor. Moreover, in both alcoholics and cocaine-dependent humans, two other factors ( 0.17 and 0.06 variance) included genes specifically involved in GABA synthesis and
Table 3 Four major subtypes of opiate receptors

\footnotetext{
${ }^{\mathrm{a}}$ The name is based on order of discovery (from Wikipedia)
}

\begin{tabular}{|c|c|c|c|}
\hline Receptor & Subtypes & Location & Function \\
\hline delta $(\delta)$ & $\delta_{1}, \delta_{2}$ & - Brain & Analgesia \\
\hline DOP & & - Pontine nuclei & Antidepressant effects \\
\hline \multirow[t]{4}{*}{$\mathrm{OP}_{1}{ }^{(\mathrm{I})}$} & & - Amygdala & Convulsant effects \\
\hline & & - Olfactory bulbs & Physical dependence \\
\hline & & - Deep cortex & Perhaps of mu-opioid \\
\hline & & - Peripheral sensory neurons & $\begin{array}{l}\text { receptor-mediated respiratory } \\
\text { depression }\end{array}$ \\
\hline kappa (к) & $\mathrm{K}_{1}, \mathrm{~K}_{2}, \mathrm{~K}_{3}$ & Brain & Analgesia \\
\hline KOP & & - Hypothalamus & Anticonvulsant effects \\
\hline \multirow[t]{6}{*}{$\mathrm{OP}_{2}{ }^{(\mathrm{I})}$} & & - Periaqueductal gray & Dissociative and delirium effects \\
\hline & & - Claustrum & Diuresis \\
\hline & & Spinal cord & Dysphoria \\
\hline & & - Substantia gelatinos & Miosis \\
\hline & & - Peripheral sensory neurons & Neuroprotection \\
\hline & & & Sedation \\
\hline $\mathrm{mu}(\mu)$ & $\mu_{1}, \mu_{2}, \mu_{3}$ & Brain & $\mu_{1}:$ \\
\hline MOP & & - Cortex (laminae III and IV) & - Analgesia \\
\hline \multirow[t]{9}{*}{$\mathrm{OP}_{3}{ }^{(\mathrm{I})}$} & & - Thalamus & - Physical dependence \\
\hline & & - Striosomes & $\mu_{2}:$ \\
\hline & & - Periaqueductal gray & - Respiratory depression \\
\hline & & - Rostral ventromedial medulla & - Miosis \\
\hline & & Spinal cord & - Euphoria \\
\hline & & - Substantia gelatinosa & - Reduced GI motility \\
\hline & & - Peripheral sensory neurons & - Physical dependence \\
\hline & & - Intestinal tract & $\mu_{3}:$ \\
\hline & & & - Possible vasodilation \\
\hline
\end{tabular}


synaptic transport showed expression changes. It has been suggested that there is specificity of GABAergic gene groups, for response to chronic alcohol/cocaine exposure. Thus, understanding the nature of GABAergic gene group specificity could have therapeutic implications for combating stress-related craving and relapse [138].

\section{Mu-Opioid Receptor Genes}

Opioid receptors are a group of G-protein coupled receptors with opioids as ligands [139-141]. The original work on these receptors occurred in the late 1960s, with the first group being that of Avram Goldstein at Stanford [142]. The endogenous opioids are dynorphins, enkephalin, endorphins, endomophins, and nociception. In 1973, Pert and Snyder were first to publish a detailed binding study of what turned out to be the mu-opioid receptor using 3H-naloxone [143], although two other studies followed shortly after $[144,145]$. The opioid receptors are $\sim 40 \%$ identical to somatostatin receptors (SSTRs). Opiate receptors are found in the spinal cord digestive tract and are distributed widely in the brain. The mu opiate receptor (OPRM) has high affinity for enkephalin, beta endorphins, and morphine.
An International Union of Basic and Clinical Pharmacology (IUPHAR) subcommittee has recommended that appropriate terminology for the four principal subtypes of opioid receptors the three classical $(\mu, \delta, \kappa)$ receptors, and the non-classical (nociception) receptor, should be MOP, DOP, KOP, and NOP, respectively [146-148] (Table 3).

\section{Genetics of the Mu Opiate Receptor Gene}

The activity at the micro-opioid receptor is central to both pain responses and opioid addiction. The opioidergic hypothesis suggests variations at the opioid receptor mu 1 (OPRM1) gene locus associate with opiate addiction. Several SNPs in exon I contained in the OPRM1 gene, which encodes for mu-opioid receptor. The polymerase chain reaction-restriction fragment length polymorphism method was used to genotype SNPs, A118G (rs 1799971) and C17T (rs 1799972) that have been associated with substance abuse. For the $118 \mathrm{G}$ allele, the opioid dependents $(n=126)$ had an approximately 2.5 -fold higher frequency of 0.31 (odds ratio 3.501; $\mathrm{CI}(95 \%) 2.212$ $5.555 ; P<0.0001)$ while the control subjects $(n=156)$ showed a frequency of 0.12 . For the $\mathrm{C} 17 \mathrm{~T}$ polymorphism, 0.83 seen in opioid dependents $(n=123$; odds ratio of $0.555 ; \mathrm{CI}(95 \%)$ $0.264-1.147 ; P=0.121)$ versus the controls $(n=57)$ showed

Table 4 Dopamine D2 receptor gene (a sampling)

\begin{tabular}{|c|c|c|c|}
\hline Polymorphism (s) & Study findings & References & Comments \\
\hline SNP rs: 1800497 & TaqA1 allele associates with sever alcoholism & Blum et al. (1990) & $\begin{array}{l}\text { First study to associate with alcoholism } \\
\text { (called reward gene) }\end{array}$ \\
\hline ANKKI -p.Glu713Lys & $\begin{array}{l}\text { DRD2 Taq1A RFLP is a single nucleotide } \\
\text { polymorphism (SNP) that causes an amino } \\
\text { acid substitution within the 11th ankyrin } \\
\text { repeat of ANKK1 }\end{array}$ & Neville et al. (2004) & $\begin{array}{l}\text { The ANKKI gene is a reflection of DRD2 } \mathrm{A}_{1} \\
\text { allele }\end{array}$ \\
\hline SNP rs: 1800497 & $\begin{array}{l}\text { This SNP has been found to predict future } \\
\text { RDS behaviors as high as } 74 \%\end{array}$ & Blum et al. (1996) & Using Bayesian analysis \\
\hline SNP rs: 1800497 & $\begin{array}{l}\text { Presence of the } \mathrm{A}^{+} \text {genotype (A1/A1, A } 1 / \\
\mathrm{A} 2) \text { compared to the } \mathrm{A}^{-} \text {genotype (A2/A2), } \\
\text { is associated with reduced density }\end{array}$ & Noble et al. (1991) & $\begin{array}{l}\text { This reduction causes hypodopaminergic } \\
\text { functioning in the dopamine reward } \\
\text { pathway }\end{array}$ \\
\hline SNP rs: 6277 at exon 7 & $\mathrm{~T}^{+}$allele associates with alcohol dependence & Hill et al. (2008) & $\begin{array}{l}\text { Associates with drug seeking behavior and } \\
\text { other RDS behaviors }\end{array}$ \\
\hline SNP rs: 1800497 & $\begin{array}{l}10 \text { year follow up that carriers of the DRD2 } \\
\text { A1 allele have a higher rate of mortality } \\
\text { compared to carriers of the A2 allele in } \\
\text { alcohol dependent individuals }\end{array}$ & Dahlgren et al. (2011) & $\begin{array}{l}\text { Taq IA1allele and a substantially increased } \\
\text { relapse rate }\end{array}$ \\
\hline $\begin{array}{l}\text { DRD2-haplotypes I-C- } \\
\text { G-A2 and I-C-A-A1 }\end{array}$ & $\begin{array}{l}\text { Confirmed the hypothesis that haplotypes, } \\
\text { which are supposed to induce a low DRD2 } \\
\text { expression, are associated with alcohol } \\
\text { dependence }\end{array}$ & $\begin{array}{l}\text { Kraschewski et al. } \\
\text { (2009) }\end{array}$ & $\begin{array}{l}\text { High frequency of haplotype was associated } \\
\text { with Cloninger Type } 2 \text { and family history } \\
\text { of alcoholism }\end{array}$ \\
\hline SNP rs: 1800497 & $\begin{array}{l}\text { Genotype analysis showed a significantly } \\
\text { higher frequency for the TaqIA } \\
\text { polymorphism among the addicts }(69.9 \%) \\
\text { compared to control subjects }(42.6 \% \text {; } \\
\text { Fisher's exact } \chi(2), P<0.05)\end{array}$ & Teh et al. (2012) & $\begin{array}{l}\text { The addicts had higher scores for novelty } \\
\text { seeking (NS) and harm avoidance (HA) } \\
\text { personality traits }\end{array}$ \\
\hline
\end{tabular}


a frequency of 0.89 for $\mathrm{C}$ allele. Thus, a significant association was observed between the $118 \mathrm{G}$ allele, and opioid dependence but no association was found with $\mathrm{C} 17 \mathrm{~T}$ polymorphism [149].

The effects of opiate drugs on pain experiences differ in humans. Recent twin studies documented individual differences, in several types of pain that are likely to be substantially determined by genetics. Genetic components to migraine pain susceptibility are documented in large twin studies, although in family studies have found substantial genetic heterogeneity in migraine. Humans $\mu \mathrm{OR}$ densities also differ. Both in vivo PET radioligand analyses and binding studies to postmortem brain samples suggest ranges of 30-50\%, or even larger, in individual differences in human $\mu \mathrm{OR}$ densities. Elucidation of the genetic basis for these differences based on receptor expression would advance substantially understanding of individual differences in and drug responses and nociceptive behaviors. The likelihood of high or low levels of expression in an individual can be predicted by information about $\mu \mathrm{OR}$ gene polymorphisms and may allow drug treatments to be individualized. These data could aid in optimization of dose ranges and selection of analgesic agents. Pain management for individuals with acute or long-term pain problems could be improved. These data could also add new therapeutic specificities and efficacies to this well-established opiate drug class, still a major weapon for amelioration of pain states [150].

Decreased analgesic effects of opioids are associated with the SNP $118 \mathrm{~A}>\mathrm{G}$ in the micro-1 opioid receptor gene (OPRM1) [151]. One recent study shows that postoperative pain response in heterozygous patients is affected by the OPRM1 118A $>$ G polymorphism. The efficacy of the analgesic therapy for postoperative pain may be impaired compared to patients with wild-type genes [151]. In another study, Liu and Wang [152] reported that the allelic frequency of variant (118G) allele was $39.6 \%$, and the prevalence of OPRM1-118 $\mathrm{AA}, \mathrm{AG}$, and GG genotypes was $31.3 \%(n=30), 58.3 \%(n=$ $56)$, and $10.4 \%(n=10)$, respectively. For all patients, pretreatment to post-treatment pain judgments were reduced significantly. Patients with AA genotype had a better analgesic effect than those with $\mathrm{G}$ allele variants (AG or GG genotypes).

Table 5 Dopamine D4 receptor gene (a sampling)

\begin{tabular}{|c|c|c|c|}
\hline Polymorphism(s) & Study findings & References & Comments \\
\hline DRD4 - The 7 repeat (7R) VNTR & $\begin{array}{l}\text { The length of the D4 dopamine receptor } \\
\text { (DRD4) exon } 3 \text { variable number of tandem } \\
\text { repeats (VNTR) affects DRD4 functioning } \\
\text { by modulating the expression and } \\
\text { efficiency of maturation of the receptor }\end{array}$ & Van Tol (1998) & $\begin{array}{l}\text { The } 7 \text { repeat (7R) VNTR requires } \\
\text { significantly higher amounts of } \\
\text { dopamine to produce a response of } \\
\text { the same magnitude as other size } \\
\text { VNTRs }\end{array}$ \\
\hline $\begin{array}{l}120 \mathrm{bp} \text { duplication, }-616 \mathrm{C} / \mathrm{G} \text {, and } \\
-521 \mathrm{C} / \mathrm{T}\end{array}$ & $\begin{array}{l}\text { Strong finding of }-120 \text { bp duplication allele } \\
\text { frequencies with schizophrenia }(P=0.008) \text {; } \\
-521 \mathrm{C} / \mathrm{T} \text { polymorphism is associated with } \\
\text { heroin addiction }\end{array}$ & Lai et al.(2010) & $\begin{array}{l}\text { This reduced sensitivity or "dopamine } \\
\text { resistance" leads to } \\
\text { hypodopaminergic functioning. Thus } \\
\text { 7R VNTR has been associated with } \\
\text { substance-seeking behavior }\end{array}$ \\
\hline DRD4 7-repeat allele & $\begin{array}{l}\text { A number of putative risk alleles using } \\
\text { survival analysis revealed that by } 25 \text { years } \\
\text { of age } 76 \% \text { of subjects with a DRD4 } 7- \\
\text { repeat allele were estimated to have } \\
\text { significantly more persistent ADHD } \\
\text { compared with } 66 \% \text { of subjects without } \\
\text { the risk allele }\end{array}$ & $\begin{array}{l}\text { Biederman } \\
\quad \text { et al. (2009) }\end{array}$ & $\begin{array}{l}\text { Findings suggest that the DRD4 7- } \\
\text { repeat allele is associated with a more } \\
\text { persistent course of ADHD }\end{array}$ \\
\hline $\begin{array}{l}\text { 7-repeat allele of the dopamine } \\
\mathrm{D}(4) \text { receptor gene (DRD4) }\end{array}$ & $\begin{array}{l}\text { Although the association between ADHD and } \\
\text { DRD4 is small, these results suggest that it } \\
\text { is real }\end{array}$ & $\begin{array}{l}\text { Faraone et al. } \\
\quad(2001)\end{array}$ & $\begin{array}{l}\text { For both the case-control and family- } \\
\text { based studies, the authors found (1) } \\
\text { support for the association between } \\
\text { ADHD and DRD4, (2) no evidence } \\
\text { that this association was accounted } \\
\text { for by any one study, and (3) no } \\
\text { evidence for publication bias }\end{array}$ \\
\hline $\begin{array}{l}\text { dopamine D4 receptor (DRD4) } \\
\text { exon } 3 \text { polymorphisms ( } 48 \text { bp } \\
\text { VNTR) }\end{array}$ & $\begin{array}{l}\text { Found significant differences in the short } \\
\text { alleles }(2-5 \text { VNTR) frequencies between } \\
\text { controls and patients with a history of } \\
\text { delirium tremens and/or alcohol seizures } \\
(P=0.043)\end{array}$ & $\begin{array}{l}\text { Grzywacz et al. } \\
\quad(2008)\end{array}$ & $\begin{array}{l}\text { A trend was also observed in the higher } \\
\text { frequency of short alleles amongst } \\
\text { individuals with an early age of onset } \\
\text { of alcoholism }(P=0.063)\end{array}$ \\
\hline $\begin{array}{l}\text { dopamine D4 receptor (DRD4) -7 } \\
\text { repeat allele }\end{array}$ & $\begin{array}{l}\text { Show 7-repeat allele is significantly over- } \\
\text { represented in the opioid-dependent cohort } \\
\text { and confers } 2.46 \mathrm{RR}\end{array}$ & $\begin{array}{l}\text { Kotler et al. } \\
\text { (1997) }\end{array}$ & $\begin{array}{l}\text { First report of an association between } \\
\text { opioid addiction and a genetic } \\
\text { polymorphism }\end{array}$ \\
\hline
\end{tabular}


Pre- and post-treatment pain judgments for patients with $\mathrm{G}$ allele variants were also reduced significantly. However, for patients with AA genotype, pre-treatment and post-treatment pain judgments were especially dramatic. The requirement for rescue analgesia also was highest for patients with $G$ allele variants. Interestingly, Setiawan et al. [153] found that one etiological pathway to alcoholism may be influenced by the A118G substitution, for which naltrexone pharmacotherapy is effective. Moreover, studies by Kranzler et al. [154] showed a modest association between OPRM1 alleles and substance (alcohol, cocaine, or opioid) dependence.

Finally, we provide a selective sample of the relationship of certain reward genes and their respective risk alleles (see Tables 4, 5, 6, 7, 8, 9, 10, 11, and 12).

\section{Genetic Addiction Risk Score Panel}

We are proposing a number of well- known risk alleles based on a plethora of literature based studies. Table 13 represents a list of each top gene (s) that should drive the risk stratification of the individual.

Understanding that RDS is a very complex polygenic disorder, we have carefully considered and chosen the primary risk alleles based on thousands of support articles in the literature. We feel confident that GARS will provide a snapshot into RDS risk. We are cognizant that this panel may change over time as new and other gene polymorphisms are discovered. Moreover, until we can develop a weighted algorithm based on utilization of "super controls" for RDS, we cannot provide a perfect test.

\section{GWAS vs Candidate Gene Approach Issues}

The need for genetic testing as a way of understanding or pinpointing therapeutic targets is certainly the wave of the future. Since the earliest study of the DRD2 gene, a remarkable list of associations with gene polymorphisms has been elucidated and eventually morphed into in the field, known today as Psychiatric Genetics. The DSM criteria are not the only method of diagnosis of psychiatric disorders. We are proposing that coupling verified standard pencil and paper tests, like the Addiction Severity Index among others, with DSM and GARS should enhance the understanding of each patient presenting for addiction treatment. In fact, it will remove guessing by providing objective risk stratification, as well as opportunities for DNA-targeted therapies (personalized addiction medicine). We are beginning to understand the power of Genome Wide Association (GWAS) [155] and EWAS studies, especially the epigenetics of gene expression via mRNA transcription. This knowledge could pave the way for either nutraceutical nutrigenomic solutions or highly specific pharmaceuticals, that by targeting select neuronal sites can reduce toxic side effects. In either case, we strongly recommend additional studies to provide the recovering addict with an epigenetic [156-158] tool to activate DA D2

Table 6 Dopamine transporter gene (DAT1)

\begin{tabular}{|c|c|c|c|}
\hline Polymorphism & Study findings & References & Comments \\
\hline $\begin{array}{l}\text { Localized to chromosome } 5 \mathrm{p} 15.3 \text {. } \\
\text { Moreover, within } 3 \text { noncoding region } \\
\text { of DAT1 lies a VNTR polymorphism - } \\
9 \text { repeat (9R) VNTR }\end{array}$ & $\begin{array}{l}\text { The } 9 \text { repeat }(9 \mathrm{R}) \text { VNTR has been shown to } \\
\text { influence gene expression and to augment } \\
\text { transcription of the dopamine transporter } \\
\text { protein }\end{array}$ & $\begin{array}{l}\text { Byerly et } \\
\text { al. } \\
\text { (1993) }\end{array}$ & $\begin{array}{l}\text { Having this variant results in an enhanced } \\
\text { clearance of synaptic dopamine, yielding } \\
\text { reduced levels of dopamine to activate } \\
\text { postsynaptic neurons }\end{array}$ \\
\hline 9 repeat $(9 \mathrm{R}) \mathrm{VNTR}$ & $\begin{array}{l}\text { DAT1, genotype } 9 / 9 \text { was associated with early } \\
\text { opiate addiction }\end{array}$ & $\begin{array}{l}\text { Galeeva } \\
\text { et al. } \\
(2002)\end{array}$ & $\begin{array}{l}\text { The combination of SERT genotype } 10 / 10 \\
\text { with DAT } 1 \text { genotype } 10 / 10 \text { was shown to be } \\
\text { a risk factor of opiate abuse less than } \\
16 \text { years of age }\end{array}$ \\
\hline $\begin{array}{l}\text { exon } 15 \text { rs } 27072 \text { and VNTR (DAT), } \\
\text { promoter VNTR and rs } 25531\end{array}$ & $\begin{array}{l}\text { The haplogenotypes 6-A-10/6-G-10 and 5-G- } \\
\text { 9/5-G-9 were more often present in type } 2 \\
\text { alcoholics as compared with type } 1 \\
\text { alcoholics [odds ratio (OR): } 2.8 \text {, and } \\
\text { controls (OR: } 5.8 \text { ), respectively }\end{array}$ & $\begin{array}{l}\text { Reese et al. } \\
\quad(2010)\end{array}$ & $\begin{array}{l}\text { In a typology proposed by Cloninger on the } \\
\text { basis of adoption studies, a subgroup has } \\
\text { been classified as type } 2 \text { with patients having } \\
\text { high genetic loading for alcoholism, an early } \\
\text { onset of alcoholism, a severe course, and } \\
\text { coexisting psychiatric problems consisting } \\
\text { of aggressive tendencies or criminality }\end{array}$ \\
\hline $\begin{array}{l}\text { VNTR polymorphism at the dopamine } \\
\text { transporter locus (DAT1) 480-bp } \\
\text { DAT1 allele }\end{array}$ & $\begin{array}{l}\text { Using the haplotype-based haplotype relative } \\
\text { risk (HHRR) method revealed significant } \\
\text { association between ADHD/UADD and the } \\
\text { 480-bp DAT1 allele (chi } 27.51,1 \mathrm{df}, P= \\
0.006 \text { ) }\end{array}$ & $\begin{array}{l}\text { Cook et al. } \\
\text { (1995) }\end{array}$ & $\begin{array}{l}\text { While there have been some inconsistencies } \\
\text { associated with the earlier results the } \\
\text { evidence is mounting in favor of the view } \\
\text { that the } 10 \mathrm{R} \text { allele of DAT is associated with } \\
\text { high risk for ADHD in children and in } \\
\text { adults alike }\end{array}$ \\
\hline
\end{tabular}


Table 7 Catechol-O-methyl-transferase (COMT) [a sampling]

\begin{tabular}{|c|c|c|c|}
\hline Polymorphism(s) & Study findings & References & Comments \\
\hline $\begin{array}{l}\text { COMT Val } 158 \text { Met variation and DRD2 } \\
\text { Taq1A genotypes }\end{array}$ & $\begin{array}{l}\text { COMT Val158Met and DRD2 Taq1A may } \\
\text { affect the intermediate phenotype of } \\
\text { central dopamine receptor sensitivity }\end{array}$ & $\begin{array}{l}\text { Schellekens } \\
\text { et al. } \\
\text { (2012) }\end{array}$ & $\begin{array}{l}\text { COMT Val158Met and DRD2 Taq1A may } \\
\text { confer their risk of alcohol dependence } \\
\text { through reduced dopamine receptor } \\
\text { sensitivity in the prefrontal cortex and } \\
\text { hindbrain, respectively }\end{array}$ \\
\hline $\begin{array}{l}\text { The functional polymorphism (COMT } \\
\text { Val108/158Met) affects COMT activity, } \\
\text { with the valine (Val) variant associated } \\
\text { with higher and the methionine (Met) } \\
\text { variant with lower COMT activity }\end{array}$ & $\begin{array}{l}\text { Male alcoholic suicide attempters, compared } \\
\text { to male non-attempters, had the higher } \\
\text { frequency of Met/Met genotype or } \\
\text { Met allele, and significantly (Kruskal- } \\
\text { Wallis ANOVA on ranks and Mann- } \\
\text { Whitney test) higher aggression and } \\
\text { depression scores }\end{array}$ & $\begin{array}{l}\text { Nedic et al. } \\
\quad(2011)\end{array}$ & $\begin{array}{l}\text { These results confirmed the associations } \\
\text { between Met allele and aggressive } \\
\text { behavior or violent suicide attempts in } \\
\text { various psychiatric diagnoses, and } \\
\text { suggested that Met allele of the COMT } \\
\text { Val108/158 Met might be used as an } \\
\text { independent biomarker of suicidal } \\
\text { behavior across different } \\
\text { psychopathologies }\end{array}$ \\
\hline COMT Val(15) Met variation & $\begin{array}{l}\text { Both controls and opiate users with Met/Met } \\
\text { genotypes showed higher NS scores } \\
\text { compared to those with the Val allele }\end{array}$ & $\begin{array}{l}\text { Demetrovis } \\
\text { et al. } \\
\text { (2010) }\end{array}$ & $\begin{array}{l}\text { Association of the COMT polymorphism } \\
\text { and NS temperament scale has been } \\
\text { shown for heroin-dependent patients and } \\
\text { controls regardless of group status }\end{array}$ \\
\hline $\begin{array}{l}\text { A functional polymorphism (COMT } \\
\text { Val158Met) resulting in increased enzyme } \\
\text { activity has been associated with } \\
\text { polysubstance abuse and addiction to } \\
\text { heroin and meth-amphetamine }\end{array}$ & $\begin{array}{l}\text { These results suggest a significant } \\
\text { association between COMT Val158Met } \\
\text { polymorphism and susceptibility to } \\
\text { cannabis dependence }\end{array}$ & $\begin{array}{l}\text { Baranse } \\
\text { et al. } \\
(2008)\end{array}$ & $\begin{array}{l}\text { Cannabis stimulates dopamine release and } \\
\text { activates dopaminergic reward neurons in } \\
\text { central pathways that lead to enhanced } \\
\text { dependence. Catechol-O-methyl } \\
\text { transferase (COMT) inactivates amplified } \\
\text { extraneuronally released dopamine }\end{array}$ \\
\hline
\end{tabular}

Table 8 Serotonin transporter gene (a sampling)

\begin{tabular}{|c|c|c|c|}
\hline Polymorphism(s) & Study findings & References & Comments \\
\hline $\begin{array}{l}\text { Serotonin transporter promoter } \\
\text { polymorphism [5-HT transporter } \\
\text { gene-linked polymorphic region } \\
\text { (5-HTTLPR)] }\end{array}$ & $\begin{array}{l}\text { 5-HTTLPR had age-dependent } \\
\text { effects on alcohol, tobacco and } \\
\text { drug use: substance use did not } \\
\text { differ by genotype at age } 9 \text {, but at } \\
\text { age } 15 \text {, the participants with the } \\
\text { short (s)/s genotype had higher } \\
\text { tobacco use, and at age } 18 \text {, they } \\
\text { were more active alcohol, drug } \\
\text { and tobacco users }\end{array}$ & $\begin{array}{l}\text { Merenäkk et al. } \\
\quad \text { (2011) }\end{array}$ & $\begin{array}{l}\text { Results reveal that expression of genetic } \\
\text { vulnerability for substance use in children } \\
\text { and adolescents may depend on age, } \\
\text { gender, interaction of genes, and type of } \\
\text { substance }\end{array}$ \\
\hline $\begin{array}{l}\text { The short (s), low activity allele of a } \\
\text { polymorphism (5-HTTLPR) in the } \\
\text { serotonin transporter gene (SLC6A4) } \\
\text { has been related to alcohol } \\
\text { dependence. }\end{array}$ & $\begin{array}{l}\text { The 5-HTTLPR short allele } \\
\text { predicted adolescent's growth } \\
\text { (slope) in alcohol use over time. } \\
\text { Adolescents with the 5-HTTLPR } \\
\text { short allele showed larger increase } \\
\text { in alcohol consumption than those } \\
\text { without the 5-HTTLPR short } \\
\text { allele }\end{array}$ & $\begin{array}{l}\text { van der Zwaluw } \\
\text { et al. (2010) }\end{array}$ & $\begin{array}{l}\text { 5-HTTLPR genotype was not related to the } \\
\text { initial level (intercept) of alcohol } \\
\text { consumption }\end{array}$ \\
\hline $\begin{array}{l}\text { triallelic 5-HTTLPR genotype : SA/SA } \\
\text { and SA/LG compared to LA/LA }\end{array}$ & $\begin{array}{l}\text { triallelic 5-HTTLPR genotype : SA/ } \\
\text { SA and SA/LG compared to LA/ } \\
\text { LA }\end{array}$ & $\begin{array}{l}\text { Kosek et al. } \\
\text { (2009) }\end{array}$ & $\begin{array}{l}\text { Previously the 5-HTTLPR s-allele has been } \\
\text { associated with higher risk of developing } \\
\text { chronic pain conditions but in this study we } \\
\text { show that the genotype coding for low 5- } \\
\text { HTT expression is associated with a better } \\
\text { analgesic effect of an opioid. The s-allele } \\
\text { has been associated with downregulation of } \\
\text { 5-HT1 receptors and we suggest that } \\
\text { individuals with a desensitization of 5-HT1 } \\
\text { receptors have an increased analgesic } \\
\text { response to opioids during acute pain } \\
\text { stimuli, but may still be at increased risk of } \\
\text { developing chronic pain conditions. }\end{array}$ \\
\hline
\end{tabular}


Table $9 \mathrm{Mu}$ opiate receptor (MOR) [a sampling]

\begin{tabular}{|c|c|c|c|}
\hline Polymorphism(s) & Study findings & References & Comments \\
\hline $\begin{array}{l}\text { A single nucleotide polymorphism (SNP) in } \\
\text { the human MOR gene (OPRM1 A118G) } \\
\text { has been shown to alter receptor protein } \\
\text { level in preclinical models and smoking } \\
\text { behavior in humans }\end{array}$ & $\begin{array}{l}\text { Independent of session, smokers } \\
\text { homozygous for the wild-type OPRM1 A } \\
\text { allele exhibited significantly higher levels } \\
\text { of MOR BP (ND) than smokers carrying } \\
\text { the G allele in bilateral amygdala, left } \\
\text { thalamus, and left anterior cingulate cortex }\end{array}$ & $\begin{array}{l}\text { Ray et al. } \\
\text { (2011) }\end{array}$ & $\begin{array}{l}\text { Among G allele carriers, the extent of } \\
\text { subjective reward difference (de- } \\
\text { nicotinized versus nicotine cigarette) was } \\
\text { associated significantly with MOR BP } \\
\text { (ND) difference in right amygdala, } \\
\text { caudate, anterior cingulate cortex, and } \\
\text { thalamus }\end{array}$ \\
\hline $\begin{array}{l}\text { Polymorphism in A118G in exon } 1 \text { and } \\
\mathrm{C} 1031 \mathrm{G} \text { in intron } 2 \text { of the MOR gene }\end{array}$ & $\begin{array}{l}\text { Results showed a significant association for } \\
\text { both } \mathrm{A} 118 \mathrm{G} \text { and } \mathrm{C} 1031 \mathrm{G} \text { polymorphisms } \\
\text { and opioid dependence. The G allele is } \\
\text { more common in the heroin-dependent } \\
\text { group ( } 39.5 \% \text { and } 30.8 \% \text { for A } 118 \mathrm{G} \text { and } \\
\text { C1031G polymorphisms, respectively) } \\
\text { when compared to the controls ( } 29.4 \% \\
\text { and } 21.1 \% \text { for A118G and C1031G } \\
\text { polymorphisms, respectively) }\end{array}$ & $\begin{array}{l}\text { Szeto et al. } \\
\qquad(2001)\end{array}$ & $\begin{array}{l}\text { This study suggests that the variant } \mathrm{G} \text { allele } \\
\text { of both A118G and } \mathrm{C} 1031 \mathrm{G} \\
\text { polymorphisms may contribute to the } \\
\text { vulnerability to heroin dependence }\end{array}$ \\
\hline $\begin{array}{l}\text { A118G single-nucleotide polymorphism } \\
\text { (SNP) in exon } 1 \text { of the MOR gene } \\
\text { (OPRM1), which encodes an amino-acid } \\
\text { substitution, is functional and receptors } \\
\text { encoded by the variant } 118 \mathrm{G} \text { allele bind } \\
\text { the endogenous opioid peptide beta- } \\
\text { endorphin with three-fold greater affinity } \\
\text { than prototype receptors. Other groups } \\
\text { subsequently reported that this variant } \\
\text { alters stress-responsivity in normal } \\
\text { volunteers and also increases the } \\
\text { therapeutic response to naltrexone (a mu- } \\
\text { preferring opioid antagonist) in the } \\
\text { treatment of alcohol dependence }\end{array}$ & $\begin{array}{l}\text { There was a significant overall association } \\
\text { between genotypes with an } 118 \mathrm{G} \text { allele } \\
\text { and alcohol dependence }(P=0.0074) \text {. The } \\
\text { attributable risk for alcohol dependence in } \\
\text { subjects with an } 118 \mathrm{G} \text { allele was } 11.1 \%\end{array}$ & $\begin{array}{c}\text { Bart et al. } \\
\quad(2005)\end{array}$ & $\begin{array}{l}\text { There was no difference in A118G genotype } \\
\text { between type } 1 \text { and type } 2 \text { alcoholics. In } \\
\text { central Sweden, the functional variant } \\
118 \mathrm{G} \text { allele in exon } 1 \text { of OPRM1 is } \\
\text { associated with an increased attributable } \\
\text { risk for alcohol dependence }\end{array}$ \\
\hline $\begin{array}{l}\text { MOR gene knockout }(\mathrm{KO}) \text { were examined in } \\
\text { wild-type }(+/+) \text {, heterozygote MOR KO } \\
(+/-) \text { and homozygote MOR KO }(-/-) \\
\text { mice on voluntary ethanol consumption }\end{array}$ & $\begin{array}{l}\text { Heterozygous and homozygous MOR KO } \\
\text { mice consumed less ethanol than wild- } \\
\text { type mice. These effects appeared to be } \\
\text { greater in female KO mice than in male } \\
\text { KO mice. MOR KO mice, especially } \\
\text { females, exhibited less ethanol reward in a } \\
\text { conditioned place preference paradigm }\end{array}$ & $\begin{array}{l}\text { Hall et al. } \\
\qquad(2001)\end{array}$ & $\begin{array}{l}\text { These data fit with the reported therapeutic } \\
\text { efficacy of MOR antagonists in the } \\
\text { treatment of human alcoholism. Allelic } \\
\text { variants that confer differing levels of } \\
\text { MOR expression could provide different } \\
\text { degrees of risk for alcoholism }\end{array}$ \\
\hline
\end{tabular}

receptors while attenuating the anti-reward effects of DA D1 and possibly D3 receptors, respectively. Finally, we as neuroscientists should begin to perform studies that control for possible comorbid medical and psychiatric conditions in the research (dual diagnosis). This work supports earlier non-genetic concepts of addiction in psychiatric medicine [159-163].

We are cognizant that there is controversy related to the importance of both GWAS and Whole-Exome Sequencing (WES) and analytical approaches relative to candidate association and linkage studies, used to unravel the contribution of specific genes and associated polymorphisms to addiction liability. In the late 1980 s realizing the complexity of the problem of both vulnerability and resilience for risk of drug abuse and other behavioral addictions, we decided to analyze candidate genes based on a theoretical model developed and subsequently published, identified as the "Brain Reward Cascade" [1]. Initially our approach utilizing this "blue print of reward" involved association rather than linkage analysis because Lander et al. argued against linkage analysis for complex disorders like drug addiction [8] instead of linkage analysis as previously accomplished with one gene one disease (OGOD).

Important advances have been made over the last two decades concerning "Psychiatric Genetics". Certainly, substantial genetic contributions to addiction liability are now supported by earlier twin studies and more recently linkage, candidate association and GWAS studies. Animal studies initially focusing upon genes that targeted mechanism of action of major drugs of abuse. Many of these studies were successful in the identification of quantitative trait loci including association of chromosomal 9 (DRD2 gene) and ethanol behavioral responses $[164,165]$ as well as other reward genes including serotonin, opioids and GABA [166]. Most of these and many other studies have identified gene/proteins that affect responses to drugs of abuse. Parallel to these animal 
Table 10 GABA beta subunit 3 (a sampling)

\begin{tabular}{|c|c|c|c|}
\hline Polymorphism(s) & Study findings & References & Comments \\
\hline $\begin{array}{l}\text { GABA A receptor beta3 subunit gene } \\
\text { (GABRB3) }\end{array}$ & $\begin{array}{l}\text { The G1- alleles of the GABRB3 in COAs } \\
\text { were significantly higher than non COAs }\end{array}$ & $\begin{array}{l}\text { Namkoong } \\
\text { et al. } \\
\text { (2008) }\end{array}$ & $\begin{array}{l}\text { In the same study the frequency of the A1+ } \\
\text { allele at DRD2 in the COAs was } \\
\text { significantly higher than non COAs }\end{array}$ \\
\hline $\begin{array}{l}\text { beta } 3 \text { subunit } m \\
\text { RNAs }\end{array}$ & $\begin{array}{l}\text { The levels of the beta } 2 \text { and beta } 3 \text { subunit } \\
\text { mRNAs remains elevated at } 24 \mathrm{~h} \\
\text { withdrawal from chronic ethanol. Chronic } \\
\text { ethanol treatment increased the levels of } \\
\text { both of these polypeptides in cerebral } \\
\text { cortex }\end{array}$ & $\begin{array}{l}\text { Mhatre and } \\
\text { Ticku } \\
\text { (1994) }\end{array}$ & $\begin{array}{l}\text { Chronic ethanol administration produced an } \\
\text { up-regulation of the beta-subunit mRNA } \\
\text { and the polypeptide expression of these } \\
\text { subunits in rat cerebral cortex }\end{array}$ \\
\hline $\begin{array}{l}\text { A1+ (A1A1 and A1A2 genotypes) and A1- } \\
\text { (A2A2 genotype) alleles of the DRD2 and } \\
\text { G1+ (G1G1 and G1 non-G1 genotypes) } \\
\text { and G1- (non-G1 non-G1 genotype) } \\
\text { alleles of the GABRB3 gene,Study } \\
\text { involved Mood-related alcohol } \\
\text { expectancy (AE) and drinking refusal self- } \\
\text { efficacy (DRSE) were assessed using the } \\
\text { Drinking Expectancy Profile. }\end{array}$ & $\begin{array}{l}\text { Patients with the DRD2 A1+ allele, } \\
\text { compared with those with the DRD2 A1- } \\
\text { allele, reported significantly lower DRSE } \\
\text { in situations of social pressure. Similarly, } \\
\text { lower DRSE was reported under social } \\
\text { pressure by patients with the GABRB3 } \\
\text { G1+ allele when compared to those with } \\
\text { the GABRB3 G1- alleles. Patients with } \\
\text { the GABRB3 G1+ allele also revealed } \\
\text { reduced DRSE in situations characterized } \\
\text { by negative affect than those with the } \\
\text { GABRB3 G1- alleles. Patients carrying } \\
\text { the GABRB3 G1+ allele showed stronger } \\
\text { AE relating to negative affective change } \\
\text { (for example, increased depression) than } \\
\text { their GABRB3 G1- counterparts }\end{array}$ & $\begin{array}{l}\text { Young } \\
\text { et al. } \\
\text { (2004) }\end{array}$ & $\begin{array}{l}\text { Molecular genetics research has identified } \\
\text { promising markers of alcohol dependence, } \\
\text { including alleles of the D2 dopamine } \\
\text { receptor (DRD2) and the GABAA } \\
\text { receptor beta3 subunit (GABRB3) genes }\end{array}$ \\
\hline $\begin{array}{l}\text { Dinucleotide repeat polymorphisms of the } \\
\text { GABA(A) receptor beta } 3 \text { subunit gene } \\
\text { were compared to scores on the General } \\
\text { Health Questionnaire-28 (GHQ) }\end{array}$ & $\begin{array}{l}\text { Analysis of GHQ subscale scores showed } \\
\text { that heterozygotes compared to the } \\
\text { combined homozygotes had higher scores } \\
\text { on the somatic symptoms }(P=0.006), \\
\text { anxiety/insomnia }(P=0.003) \text {, social } \\
\text { dysfunction }(P=0.054) \text { and depression } \\
(P=0.004) \text { subscales }\end{array}$ & $\begin{array}{l}\text { Feusner } \\
\text { et al. } \\
(2001)\end{array}$ & $\begin{array}{l}\text { The study indicates that in a population of } \\
\text { PTSD patients, heterozygosity of the } \\
\text { GABRB3 major (G1) allele confers higher } \\
\text { levels of somatic symptoms, anxiety/ } \\
\text { insomnia, social dysfunction and } \\
\text { depression than found in homozygosity }\end{array}$ \\
\hline $\begin{array}{l}\text { GABRB3 major (G1) allele and DRD@A1 } \\
\text { allele }\end{array}$ & $\begin{array}{l}\text { A significant progressive increase was } \\
\text { observed in DRD2 A1 allelic prevalence } \\
(P=3.1 \times 10(-6)) \text { and frequency }(P=2.7 \times \\
10(-6)) \text { in the order of non-alcoholics, less } \\
\text { severe and severe alcoholics. In severe } \\
\text { alcoholics, compared to non-alcoholics, a } \\
\text { significant decrease was found in the } \\
\text { prevalence }(P=4.5 \times 10(-3)) \text { and } \\
\text { frequency }(P=2.7 \times 10(-2)) \text { of the } \\
\text { GABRB3 major }(\mathrm{G} 1) \text { allele. Furthermore, } \\
\text { a significant progressive decrease was } \\
\text { noted in } \mathrm{G} 1 \text { allelic prevalence }(P=2.4 \times 10 \\
(-3)) \text { and frequency }(P=1.9 \times 10(-2)) \text { in } \\
\text { non-alcoholics, less severe and severe } \\
\text { alcoholics, respectively }\end{array}$ & $\begin{array}{l}\text { Noble et al. } \\
\text { (1988) }\end{array}$ & $\begin{array}{l}\text { In sum, in the same population of non- } \\
\text { alcoholics and alcoholics studied, variants } \\
\text { of both the DRD2 and GABRB3 genes } \\
\text { independently contribute to the risk for } \\
\text { alcoholism, with the DRD2 variants } \\
\text { revealing a stronger effect than the } \\
\text { GABRB3 variants. However, when the } \\
\text { DRD2 and the GABRB3 variants are } \\
\text { combined, the risk for alcoholism is more } \\
\text { robust than when these variants are } \\
\text { considered separately }\end{array}$ \\
\hline
\end{tabular}

studies, human genetic research has evolved over the last 5 years. Now, it is possible to detect genetic variation in the human genome inexpensively. The era of genome sequencing began with the detection of SNPs on gene chips. Very recently, we are also utilizing WES, which is a high-throughput sequencing, to identify the molecular arrangement of DNA base pairs specifying the coding regions of a person's genome also referred to as the exome. While this is exciting, it may not have clinical utility because the exome only comprises about $1 \%$ of the entire genome [167].
When compared to the enormous literature on candidate gene analysis (6120 studies) currently there is a paucity of GWAS/WES studies relevant to addiction liability (239 studies). A commentary by Hall et al. [168] from NIDA and others have argued that candidate gene analysis may be wrong. However, they do suggest the following from many GWAS studies: (1) addiction is highly polygenic, each allelic variant contributing in a small, additive (counting) amount to addiction liability; (2) classes of genes (such as reward circuitry based genes) are most important in explaining 
Table 11 MOA-A (a sampling)

\begin{tabular}{|c|c|c|c|}
\hline Polymorphism(s) & Study findings & References & Comments \\
\hline MAOA genotype & $\begin{array}{l}\text { Significant three-way interactions, MAOA } \\
\text { genotype by abuse by sex, predicted dysthymic } \\
\text { symptoms. Low-activity MAOA genotype } \\
\text { buffered against symptoms of dysthymia in } \\
\text { physically abused and multiply-maltreated } \\
\text { women. Significant three-way interactions, } \\
\text { MAOA genotype by sexual abuse by race, } \\
\text { predicted all outcomes. Low-activity MAOA } \\
\text { genotype buffered against symptoms of } \\
\text { dysthymia, major depressive disorder, and } \\
\text { alcohol abuse for sexually abused white } \\
\text { participants. The high-activity genotype was } \\
\text { protective in the nonwhite sexually abused group }\end{array}$ & $\begin{array}{l}\text { Nikulina et al. } \\
\text { (2012) }\end{array}$ & $\begin{array}{l}\text { This prospective study provides } \\
\text { evidence that MAOA interacts with } \\
\text { child maltreatment to predict mental } \\
\text { health outcomes }\end{array}$ \\
\hline low-repeat MAOA allele & $\begin{array}{l}\text { Individuals with CUD had reductions in GMV in the } \\
\text { orbitofrontal, dorsolateral prefrontal, and } \\
\text { temporal cortex and the hippocampus compared } \\
\text { with controls. (2) The orbitofrontal cortex } \\
\text { reductions were uniquely driven by CUD with } \\
\text { low- MAOA genotype and by lifetime cocaine } \\
\text { use }\end{array}$ & $\begin{array}{l}\text { Alia-Klein } \\
\quad \text { et al. (2011) }\end{array}$ & $\begin{array}{l}\text { Long-term cocaine users with the low- } \\
\text { repeat MAOA allele have enhanced } \\
\text { sensitivity to gray matter loss, } \\
\text { specifically in the orbitofrontal } \\
\text { cortex, indicating that this genotype } \\
\text { may exacerbate the deleterious } \\
\text { effects of cocaine in the brain }\end{array}$ \\
\hline MAOA u-VNTR & $\begin{array}{l}\text { Girls, carrying the long MAOA u-VNTR variant } \\
\text { showed a higher risk of being high alcohol } \\
\text { consumers, whereas among boys, the short allele } \\
\text { was related to higher alcohol consumption }\end{array}$ & $\begin{array}{l}\text { Nilsson et al. } \\
\text { (2011) }\end{array}$ & $\begin{array}{l}\text { The present study supports the } \\
\text { hypothesis that there is a relation } \\
\text { between MAOA u-VNTR and } \\
\text { alcohol consumption and that this } \\
\text { relation is modulated by } \\
\text { environmental factors }\end{array}$ \\
\hline
\end{tabular}

30-bp repeat in the promoter region of the monoamine oxidase-A gene (MAO-A)

The Revised Psychopathy Checklist (PCL-R) has shown a moderate association with violence and as such studied with MAOA genotyped alcoholic offenders

Genotyping of two functional polymorphisms in the promoter region of the serotonin transporter and monoamine oxidase-A, respectively, (5-HTT-LPR and MAOA-VNTR), was performed in a group of women with severe alcohol addiction.

The MAOA gene presents several polymorphisms including a 30-bp VNTR in the promoter region (MAOA-uVNTR). Alleles with 3.5 and 4 repeats are $2-10$ times more efficient than 3 -repeat allele.
Significant associations between cold pain tolerance and DAT-1 $(P=0.008)$ and MAO-A $(P=0.024)$ polymorphisms were found. Specifically, tolerance was shorter for carriers of allele 10 and the rarer allele 11 , as compared to homozygous for allele 9 , and for carriers of allele 4 (MOA) as compared to homozygous for allele 3 , respectively

The PCL-R total score predicts impulsive reconvictions among high-activity MAOA offenders (6.8\% risk increase for every one-point increase in PCL-R total score, $P=0.015$ ), but not among low-activity MAOA offenders, whereas antisocial behavior and attitudes predicted reconvictions in both genotypes $(17 \%$ risk increase among high-activity MAOA offenders and $12.8 \%$ increase among low-activity MAOA offenders for every one-point increase in factor 2 score)

Within the group of alcoholics, when the patients with known co-morbid psychiatric disorders were excluded, aggressive anti-social behavior was significantly linked to the presence of the high activity MAOA allele

The results suggest that the 3-repeat allele is associated to: (1) alcohol dependence $(P<0.05)$; (2) an earlier onset of alcoholism $(P<0.01)$; (3) comorbid drug abuse among alcoholics $(P<0.05)$; and (4) a higher number of antisocial symptoms $(P<0.02)$
Treister et al. (2009)

These results, together with the known function of the investigated candidate gene polymorphisms, suggest that low dopaminergic activity can be associated with high pain sensitivity and vice versa

Tikkanen et al. Results suggest that the efficacy of (2011)

Gokturk et a (2008)

Contini et al. Results confirmed reports showing an (2006) association of the low activity 3-repeat allele of MAOA uVNTR polymorphism with substance dependence and impulsive, antisocial behaviors. These findings in a different culture support influence of MAOA-u VNTR in psychiatric illness 
Table 12 Dopamine D3 (a sampling)

\begin{tabular}{|c|c|}
\hline Polymorphism(s) & Study findings \\
\hline $\begin{array}{l}\text { The genotypes of the BDNF } \\
\text { Val66Met and DRD3 Ser9Gly } \\
\text { polymorphisms. BDNF regulates } \\
\text { expression of D3. }\end{array}$ & $\begin{array}{l}\text { Logistic regression analysis showed a significant } \\
\text { main effect for the Val/Val genotype of the } \\
\text { BDNF Val66Met polymorphism }(P=0.020) \text {, } \\
\text { which predicted bipolar-II patients. Significant } \\
\text { interaction effects for the BDNF Val66Met } \\
\text { Val/Val genotype and both DRD3 Ser9Gly } \\
\text { Ser/Ser and Ser/Gly genotypes were found } \\
\text { only in bipolar-II patients }(P=0.027 \text { and } \\
0.006 \text {, respectively) }\end{array}$ \\
\hline D3R KO mice. & $\begin{array}{l}\text { The possible interaction between morphine- } \\
\text { induced tolerance and D3 receptors has not } \\
\text { been investigated. Compared with wild-type } \\
\text { (WT) mice, the dopamine D3 receptor } \\
\text { knockout (D3R KO) mice showed } \\
\text { pronounced hypoalgesia. The D3R KO mice } \\
\text { clearly developed lower morphine-induced } \\
\text { tolerance and showed attenuated withdrawal } \\
\text { signs compared with the WT mice }\end{array}$ \\
\hline $\begin{array}{l}\text { DNA microarrays of two different } \\
\text { alcohol-preferring rat lines (HAD } \\
\text { and P) and D3 receptors. }\end{array}$ & $\begin{array}{l}\text { Data revealed an up-regulation of the dopamine } \\
\text { D3 receptor (D3R) after } 1 \text { year of voluntary } \\
\text { alcohol consumption in the striatum of alcohol } \\
\text { preferring rats that was confirmed by qRT- } \\
\text { polymerase chain reaction }\end{array}$ \\
\hline
\end{tabular}

Gly9 homozygotes in comparison to Ser9 carriers of D3 receptor gene.

Dopamine receptor D3 gene Ball polymorphism.

Bal I polymorphism at the DRD3 gene

mRNA of both DRD2 and DRD3 gene expression

References Comments

BDNF Val66Met polymorphism $(P=0.020)$, interaction effects for the BDNF Val66Met only in bipolar-II patients $(P=0.027$ and he possible interaction between morphinebeen investigated. Compared with wild-type WT) mice, the dopamine D3 receptor clearly developed lower morphine-induced tolerance and showed attenuated withdrawa signs compared with the WT mice Data revealed an up-regulation of the dopamine polymerase chain reaction

German descent and have found diminished parietal and increased frontal P300 amplitudes in Gly9 homozygotes in comparison to Ser9 carriers. Further studies should address the direct role of the DRD3 Ser9Gly polymorphism in attenuated P300 amplitudes in psychiatric disorders like schizophrenia or alcoholism

Patients above the median value for cognitive impulsiveness (one of the three dimensions of the Barratt scale) were more frequently heterozygous than both alcohol-dependent patients with lower impulsiveness $(\mathrm{OR}=2.51$, $P=0.019)$ and than 71 healthy controls $(\mathrm{OR}=$ $2.32, P=0.025$ )

Patients with a sensation-seeking score above 24 were more frequently homozygotes for both alleles than patients with a sensation-seeking score under $24(P=0.038)$ or controls $(P=$ $0.034)$

After a chronic schedule of intermittent bingeing on a sucrose solution, mRNA levels for the D2 dopamine receptor, and the preproenkephalin and preprotachykinin genes were decreased in dopamine-receptive regions of the forebrain, while D3 dopamine receptor mRNA was increased. The effects of sugar on mRNA levels were of greater magnitude in the nucleus accumbens than in the caudate-putamen
Lee et al.

Evidence that the BDNF Val66Met and DRD3 Ser9Gly genotypes interact only in bipolar-II disorder (hypomania) and that bipolar-I (Mania) and bipolar-II may be genetically distinct

Li et al. These results suggest that $\mathrm{D} 3$ receptors regulate (2012) basal nociception and are involved in the development of morphine-induced tolerance and withdrawal

Vengeliene Long-term alcohol consumption leads to an upet al. (2006) regulation of the dopamine $\mathrm{D} 3 \mathrm{R}$ that may contribute to alcohol-seeking and relapse. We therefore suggest that selective antagonists of this pharmacological target provide a specific treatment approach to reduce alcohol craving and relapse behavior

Mulert

et al.

An important reason for the interest in P300 event-related potentials are findings in patients with psychiatric disorders like schizophrenia or alcoholism in which attenuations of the P300 amplitude are common findings

Limosin

et al. (2005)

The D3 Receptor gene has been associated with addictive behaviors especially impulsiveness

These results suggest that the DRD3 gene may et al. have a role in drug dependence susceptibility (1998) in individuals with high sensation-seeking scores

Striatal regions of sugar-dependent rats show alterations in dopamine and opioid mRNA levels similar to morphine-dependent rats both risk and resilience to all addictions and (3) substantial genetic heterogeneity exists, and there is a convergence of GWAS signals on particular candidategenes.
It is well-known that the action of psychoactive drugs primarily affects synaptic neurotransmission. Reynolds et al. [169] correctly suggest that specific genes for neurotransmitter receptors and transporters have provided strong candidates in 
Table 13 GARS panel

\begin{tabular}{|c|c|c|}
\hline Gene & Allele & Prime function \\
\hline Dopamine D1 Receptor & $48 \mathrm{G}$ & Regulation of dopamine release in accumbens \\
\hline Dopamine D2 Receptor (ANKKI/DRD2) & Taq I A1 & Controls synthesis of dopamine D2 receptors \\
\hline Dopamine D3 Receptor (DRD3) & $\mathrm{C}$ & $\begin{array}{l}\text { Carriers sensitive to cocaine; opioids, alcohol } \\
\text { and nicotine }\end{array}$ \\
\hline Dopamine D4 Receptor (DRD4) & $7 \mathrm{R}$ & Pre-disposed to novelty seeking and ADHD \\
\hline Dopamine Transporter (DAT1) & $9 \mathrm{R}$ & $\begin{array}{l}\text { Fast transport of synaptic dopamine back into } \\
\text { pre-neuron leading to hypodopaminergic trait. }\end{array}$ \\
\hline Serotonin Transporter (HTTLPR) & $\mathrm{S}$ & Fast transport of serotonin back into neuron \\
\hline Mu-opiate Receptor (OPRM1) & G & Predisposes to heroin addiction and pain sensitivity \\
\hline GABA B $_{3}$ Receptor (GABAR3) & 181. & Predisposes to anxiety disorders \\
\hline Mono-Amine Oxidase A (MAO-uVNTR) & $4 \mathrm{R}$ & Fast catabolism of mitochondria dopamine \\
\hline $\begin{array}{l}\text { Catecholamine Methyl-Transferase } \\
\text { (COMT-vall58met) }\end{array}$ & G & $\begin{array}{l}\text { Val substitution leads to fast catabolism of synaptic } \\
\text { dopamine leading to RDS }\end{array}$ \\
\hline
\end{tabular}

pharmacogenetic research in psychiatry. Moreover, there are many inconsistencies between candidate gene and GWAS studies. Reynolds further suggests that consistencies have accumulated through candidate gene studies involving the dopamine D2 receptor; serotonin transporter; and GABA dysfunction in mental illness. Moreover, Han et al. [170] reported that following GWAS, functional enrichment analysis revealed specific genes to underlie alcohol risk such as cation transport, synaptic transmission, and transmission of nerve impulses representing meaningful biological processes. In agreement, Uhl et al. [171] suggest that following GWAS, clusters of SNPs within selected genes display $10(-2)>P>10(-8)$ associations with dependence in many independent studies. Importantly, along these lines, specific candidate genes associated with substance dependence phenotypes, for example, in Native Americans, these include OPRM1, CRN1, COMT, GABA2, MAOA, and HTR3-B [172]. In a cross-species GWAS study to access risk genes, in alcoholism, it was found that 47 genes associated including GABA, signaling pathway and cell communication [173]. In one study using GWAS and factor analysis, Agrawal et al. [174] found a high loading (0.89) for alcohol craving and convergence resulted in an association of SNPs in DRD3 and craving.

While there are many more examples showing promising convergence between GWAS and candidate gene analyses, albeit others showing no convergence, $\mathrm{Li}$ et al. [175] performed a meta-analysis of addiction candidate gene association studies and GWAS to investigate functional mechanisms linked to addiction risk. When they compared the lists of genes identified by molecular biological studies of drugrelated genes and those by association studies, they observed significantly higher participation in the same gene interaction networks than expected by chance. This work is underscored by Li's earlier work, the KARG analysis that evaluated 1,500 human genes regulating addictive behaviors and found that these genes significantly impact glutaminergic and dopaminergic pathways [176].

GWAS studies in psychiatry frequently fail to explain a large proportion of variance and non-replication of individual SNPs. Derringer et al. [177] utilizing a "selective scoring" whereby variants (273 SNPs) from eight dopamine-related genes for association with cocaine dependence were considered. They identified a four SNP score significantly associated with the variance. They suggested that (1) limiting SNPs to genes of theoretical importance improves the chances of identifying replicable effects (2) utilizing this scoring approach which considers top-associated SNPs in the aggregate can reveal replicable effects that are too small to be identified at the level of individual SNPs. Along with these precautions we also propose the utilization of "super controls" to eliminate cross contamination of having a control phenotype that also carries the associated disorder especially when considering the complex nature of RDS. Also in developing GARS we are cognizant that the proposed test only provides risk stratification and not actual diagnosis of any disorder including RDS. Most importantly, full comprehension of "psychiatric pharmacogenomics" will undoubtedly involve epigenetic factors, such as DNA histone modifications, for example, methylation and or acetylation that can affect responses to drugs and polymorphic antecedents for either vulnerability or resilience to reward behaviors like RDS, as well as, GWAS convergence to candidate genes [178-185].

Moreover, the utilization of GARS in the clinic has benefits other than just risk stratification, such as, potential therapeutic targets, reduced denial, medical monitoring, for example, in terms of pharmacogenomic tagging [186]. Moreover, we are cognizant that certain ethnic groups will have different rates of polymorphic genes as well different rates of gene polymorphic frequencies [187], and we are developing an algorithm to address this issue involving weighting. In addition, we are 
analyzing additional data including a total of 393 subjects derived from 9 treatment centers of which 320 have taken the Addiction Severity Index (ASI).

The problem of GWAS is that a general conclusion from GWAS is that most polymorphisms confer little risk increments and explain a small portion of heritability. One example is that 40 loci have been associated with human height, with a known heritability of about $80 \%$, but those total variants explain only $5 \%$ of the phenotypic variance. It has been suggested that a main problem with GWAS is the need for a level of multiple statistical comparisons that are unprecedented in biology, with stringent analyses to achieve genome-wide significance [186]. In fact, Belcher et al. [188] suggest there is clear evidence to support a genetic basis for SUD. While these authors consider personality as an appropriate endophenotype, we argue that the real endophenotype is RDS as we suggested in the generational study [18]. Certainly, there are a number of studies showing enhanced relapse with specific polymorphisms such as carriers of the DRD2 A1 allele as only one example [189]. Finally, as we pointed out herein, there are fairly recent studies showing GWAS convergence to candidate genes suggesting the continued importance of the candidate approach to identify genetic risk [166-177].

\section{Conclusion}

We encourage further work in the area of psychiatric genetics like GARS and new technology like CARD to track patients during recovery more intensively. While GARS may not be perfect as yet and more research is necessary in the near future, we should not at this point "throw out the baby with the bath water." Utilization of these suggested new technologies should impact the "revolving door" and secure significant reduction in relapse.

\begin{abstract}
Acknowledgments The writing of this paper was supported in part by funds from the National Institutes of Health, NIAAA (RO1-AA07112 and K05-AA00219) and the Medical Research Service of the US Department of Veterans Affairs (MOB). The authors appreciate the editorial assistance of Margaret A. Madigan and Paula J. Edge. Kenneth Blum is the recipient of a grant to PATH FOUNDATION NY, by Life Extension Foundation, Ft/Lauderdale, Florida.
\end{abstract}

Conflicts of Interest Kenneth Blum, PhD holds certain US and foreign patents related to genetic testing which has been licensed to Dominion Diagnostics. Dr. Blum is also an officer and stock holder of IGENE, LLC and is a paid consultant of Dominion Diagnostics, LLC., IGENE, and Malibu Recovery Center. Dr. Blum is a member of the scientific advisory board of Dominion Diagnostics, LLC and Chief Scientific Adviser.

Open Access This article is distributed under the terms of the Creative Commons Attribution License which permits any use, distribution, and reproduction in any medium, provided the original author(s) and the source are credited.

\section{References}

1. Blum K, Kozlowski GP (1990) Ethanol and neuromodulator interactions: a cascade model of reward. In: Ollat $\mathrm{H}$, Parvez S, Parvez H (eds) Alcohol and behavior. VSP, Utrecht, pp 131-149

2. Noble EP (2003) D2 dopamine receptor gene in psychiatric and neurologic disorders and its phenotypes. Am J Med Genet Part B Neuropsychiatr Genet Off Publ Int Soc Psychiatr Genet 116B(1): 103-125. doi:10.1002/ajmg.b.10005

3. Thanos PK, Volkow ND, Freimuth P, Umegaki H, Ikari H, Roth G, Ingram DK, Hitzemann R (2001) Overexpression of dopamine D2 receptors reduces alcohol self-administration. J Neurochem 78(5): 1094-1103

4. Conner BT, Hellemann GS, Ritchie TL, Noble EP (2010) Genetic, personality, and environmental predictors of drug use in adolescents. J Subst Abus Treat 38(2):178-190. doi:10.1016/j.jsat.2009. 07.004

5. Bossert JM, Liu SY, Lu L, Shaham Y (2004) A role of ventral tegmental area glutamate in contextual cue-induced relapse to heroin seeking. J Neurosci Off J Soc Neurosci 24(47):10726-10730. doi:10.1523/JNEUROSCI.3207-04.2004

6. Li CY, Mao X, Wei L (2008) Genes and (common) pathways underlying drug addiction. PLoS Comput Biol 4(1):e2. doi:10. 1371/journal.pcbi.0040002

7. Blum K, Noble EP, Sheridan PJ, Montgomery A, Ritchie T, Jagadeeswaran P, Nogami H, Briggs AH, Cohn JB (1990) Allelic association of human dopamine D2 receptor gene in alcoholism. JAMA J Am Med Assoc 263(15):2055-2060

8. Lander ES, Schork NJ (1994) Genetic dissection of complex traits. Science (New York, NY) 265(5181):2037-2048

9. Chanock SJ, Manolio T, Boehnke M, Boerwinkle E, Hunter DJ, Thomas G, Hirschhorn JN, Abecasis G, Altshuler D, Bailey-Wilson JE, Brooks LD, Cardon LR, Daly M, Donnelly P, Fraumeni JF Jr, Freimer NB, Gerhard DS, Gunter C, Guttmacher AE, Guyer MS, Harris EL, Hoh J, Hoover R, Kong CA, Merikangas KR, Morton CC, Palmer LJ, Phimister EG, Rice JP, Roberts J, Rotimi C, Tucker MA, Vogan KJ, Wacholder S, Wijsman EM, Winn DM, Collins FS (2007) Replicating genotype-phenotype associations. Nature 447 (7145):655-660. doi:10.1038/447655a

10. Chen AL, Chen TJ, Waite RL, Reinking J, Tung HL, Rhoades $P$, Downs BW, Braverman E, Braverman D, Kerner M, Blum SH, DiNubile N, Smith D, Oscar-Berman M, Prihoda TJ, Floyd JB, O'Brien D, Liu HH, Blum K (2009) Hypothesizing that brain reward circuitry genes are genetic antecedents of pain sensitivity and critical diagnostic and pharmacogenomic treatment targets for chronic pain conditions. Med Hypotheses 72(1):14-22. doi:10. 1016/j.mehy.2008.07.059

11. Blum K, Sheridan PJ, Wood RC, Braverman ER, Chen TJ, Cull JG, Comings DE (1996) The D2 dopamine receptor gene as a determinant of reward deficiency syndrome. J R Soc Med 89(7):396-400

12. Blum K, Braverman ER, Holder JM, Lubar JF, Monastra VJ, Miller D, Lubar JO, Chen TJ, Comings DE (2000) Reward deficiency syndrome: a biogenetic model for the diagnosis and treatment of impulsive, addictive, and compulsive behaviors. J Psychoactive Drugs 32(Suppl:i-iv):1-112

13. Comings DE, Blum K (2000) Reward deficiency syndrome: genetic aspects of behavioral disorders. Prog Brain Res 126:325-341. doi: 10.1016/S0079-6123(00)26022-6

14. Blum K (2012) Chapter 26, neurogenetics and nutrigenomics of reward deficiency syndrome. In: Barth RJ, Blum K, Madigan M (eds) Omics-biomedical perspectives and applications. CRC (Taylor \& Francis), Boca Raton, pp 535-576

15. Blum K, Oscar-Berman M, Stuller E, Miller D, Giordano J, Morse S, McCormick L, Downs WB, Waite RL, Barh D, Neal D, Braverman ER, Lohmann R, Borsten J, Hauser M, Han D, Liu Y, 
Helman M, Simpatico T (2012) Neurogenetics and nutrigenomics of neuro-nutrient therapy for reward deficiency syndrome (RDS): clinical ramifications as a function of molecular neurobiological mechanisms. J Addict Res Ther 3(5):139. doi:10.4172/2155-6105. 1000139

16. Dackis CA, Gold MS (1985) New concepts in cocaine addiction: the dopamine depletion hypothesis. Neurosci Bio Rev 9:469-477

17. Gold MS, Redmond DE Jr, Kleber HD (1978) Clonidine blocks acute opiate-withdrawal symptoms. Lancet 2(8090):599-602

18. Blum K, Chen AL, Oscar-Berman M, Chen TJ, Lubar J, White N, Bowirrat A, Braverman E, Schoolfield J, Waite RL, Downs BW, Madigan M, Comings DE, Davis C, Kerner MM, Knopf J, Palomo T, Giordano JJ, Morse SA, Fornari F, Barh D, Femino J, Bailey JA (2011) Generational association studies of dopaminergic genes in reward deficiency syndrome (RDS) subjects: selecting appropriate phenotypes for reward dependence behaviors. Int J Environ Res Public Health 8(12):4425-4459. doi:10.3390/ijerph8124425

19. Chen TJ, Blum K, Mathews D, Fisher L, Schnautz N, Braverman ER, Schoolfield J, Downs BW, Comings DE (2005) Are dopaminergic genes involved in a predisposition to pathological aggression? hypothesizing the importance of "super normal controls" in psychiatricgenetic research of complex behavioral disorders. Med Hypotheses 65(4):703-707. doi:10.1016/j.mehy.2005.04.037

20. Mayes LC, Granger RH, Bornstein MH, Zuckerman B (1992) The problem of prenatal cocaine exposure. A rush to judgment. JAMA J Am Med Assoc 267(3):406-408

21. David V, Matifas A, Gavello-Baudy S, Decorte L, Kieffer BL, Cazala P (2008) Brain regional Fos expression elicited by the activation of mu- but not delta-opioid receptors of the ventral tegmental area: evidence for an implication of the ventral thalamus in opiate reward. Neuropsychopharmacol Off Publ Am Coll Neuropsychopharmacol 33(7):1746-1759. doi:10.1038/sj.npp. 1301529

22. Bond C, LaForge KS, Tian M, Melia D, Zhang S, Borg L, Gong J, Schluger J, Strong JA, Leal SM, Tischfield JA, Kreek MJ, Yu L (1998) Single-nucleotide polymorphism in the human mu opioid receptor gene alters beta-endorphin binding and activity: possible implications for opiate addiction. Proc Natl Acad Sci U S A 95(16): 9608-9613

23. Ide S, Minami M, Satoh M, Uhl GR, Sora I, Ikeda K (2004) Buprenorphine antinociception is abolished, but naloxonesensitive reward is retained, in mu-opioid receptor knockout mice. Neuropsychopharmacol Off Publ Am Coll Neuropsychopharmacol 29(9):1656-1663. doi:10.1038/sj.npp.1300463

24. Enoch MA, Hodgkinson CA, Gorodetsky E, Goldman D, Roy A (2013) Independent effects of 5' and 3' functional variants in the serotonin transporter gene on suicidal behavior in the context of childhood trauma. J Psychiatr Res 47(7):900-907. doi:10.1016/j. jpsychires.2013.03.007

25. Vaske J, Newsome J, Wright JP (2012) Interaction of serotonin transporter linked polymorphic region and childhood neglect on criminal behavior and substance use for males and females. Dev Psychopathol 24(1):181-193. doi:10.1017/S0954579411000769

26. Saiz PA, Garcia-Portilla MP, Arango C, Morales B, MartinezBarrondo S, Alvarez C, San Narciso G, Carreno E, Alvarez V, Coto E, Bobes J (2008) Association between heroin dependence and 5-HT2A receptor gene polymorphisms. Eur Addict Res 14(1): 47-52. doi:10.1159/000110410

27. Herman AI, Conner TS, Anton RF, Gelernter J, Kranzler HR, Covault J (2011) Variation in the gene encoding the serotonin transporter is associated with a measure of sociopathy in alcoholics. Addict Biol 16(1):124-132. doi:10.1111/j.1369-1600.2009.00197. $\mathrm{x}$

28. Jakubczyk A, Klimkiewicz A, Kopera M, Krasowska A, Wrzosek M, Matsumoto H, Burmeister M, Brower KJ, Wojnar M (2013) The CC genotype in the T102C HTR2A polymorphism predicts relapse in individuals after alcohol treatment. J Psychiatr Res 47(4):527533. doi:10.1016/j.jpsychires.2012.12.004

29. Herin DV, Bubar MJ, Seitz PK, Thomas ML, Hillman GR, Tarasenko YI, Wu P, Cunningham KA (2013) Elevated expression of serotonin 5-HT(2A) receptors in the rat ventral tegmental area enhances vulnerability to the behavioral effects of cocaine. Front Psychiatry 4:2. doi:10.3389/fpsyt.2013.00002

30. White AH, Wilson JF, Burns A, Blum-Kemelor D, Singh A, Race PO, Soto V, Lockett AF (2011) Use of qualitative research to inform development of nutrition messages for low-income mothers of preschool children. J Nutr Educ Behav 43(1):19-27. doi:10.1016/ j.jneb.2009.10.002

31. do Prado-Lima PA, Chatkin JM, Taufer M, Oliveira G, Silveira E, Neto CA, Haggstram F, Bodanese LC, da Cruz IB (2004) Polymorphism of 5HT2A serotonin receptor gene is implicated in smoking addiction. Am J Med Genetics Part B Neuropsychiatric genet Off Publ Int Soc Psychiatr Genet 128B(1):90-93. doi:10. 1002/ajmg.b.30004

32. Nichols CD, Garcia EE, Sanders-Bush E (2003) Dynamic changes in prefrontal cortex gene expression following lysergic acid diethylamide administration. Brain Res Mol Brain Res 111(1-2): 182-188

33. Otten R, Engels RC (2013) Testing bidirectional effects between cannabis use and depressive symptoms: moderation by the serotonin transporter gene. Addict Biol 18(5):826-835. doi:10.1111/j. 1369-1600.2011.00380.x

34. Treister R, Pud D, Ebstein RP, Laiba E, Raz Y, Gershon E, Haddad M, Eisenberg E (2011) Association between polymorphisms in serotonin and dopamine-related genes and endogenous pain modulation. J Pain Off J Am Pain Soc 12(8):875-883. doi:10.1016/j. jpain.2011.02.348

35. Kosek E, Jensen KB, Lonsdorf TB, Schalling M, Ingvar M (2009) Genetic variation in the serotonin transporter gene (5-HTTLPR, rs25531) influences the analgesic response to the short acting opioid Remifentanil in humans. Mol Pain 5:37. doi:10.1186/1744-8069-537

36. Pinto E, Reggers J, Gorwood P, Boni C, Scantamburlo G, Pitchot W, Ansseau M (2008) The short allele of the serotonin transporter promoter polymorphism influences relapse in alcohol dependence. Alcohol Alcohol 43(4):398-400. doi:10.1093/alcalc/agn015

37. Sery O, Didden W, Mikes V, Pitelova R, Znojil V, Zvolsky P (2006) The association between high-activity COMT allele and alcoholism. Neuro Endocrinol Lett 27(1-2):231-235

38. Cao L, Li T, Liu X (2003) Association study of heroin dependence and catechol-O-methyltransferase gene. Zhonghua yi xue yi chuan xue za zhi $=$ Zhonghua yixue yichuanxue zazhi Chin J Med Genet 20(2):127-130

39. Vandenbergh DJ, Rodriguez LA, Hivert E, Schiller JH, Villareal G, Pugh EW, Lachman H, Uhl GR (2000) Long forms of the dopamine receptor (DRD4) gene VNTR are more prevalent in substance abusers: no interaction with functional alleles of the catechol-omethyltransferase (COMT) gene. Am J Med Genet 96(5):678-683

40. Pelayo-Teran JM, Suarez-Pinilla P, Chadi N, Crespo-Facorro B (2012) Gene-environment interactions underlying the effect of cannabis in first episode psychosis. Curr Pharm Des 18(32):5024-5035

41. Al-Eitan LN, Jaradat SA, Hulse GK, Tay GK (2012) Custom genotyping for substance addiction susceptibility genes in Jordanians of Arab descent. BMC Res Notes 5:497. doi:10.1186/ 1756-0500-5-497

42. Li T, Yu S, Du J, Chen H, Jiang H, Xu K, Fu Y, Wang D, Zhao M (2011) Role of novelty seeking personality traits as mediator of the association between COMT and onset age of drug use in Chinese heroin dependent patients. PLoS One 6(8):e22923. doi:10.1371/ journal.pone. 0022923

43. Demetrovics Z, Varga G, Szekely A, Vereczkei A, Csorba J, Balazs H, Hoffman K, Sasvari-Szekely M, Barta C (2010) Association 
between Novelty Seeking of opiate-dependent patients and the catechol-O-methyltransferase Val(158)Met polymorphism. Compr Psychiatry 51(5):510-515. doi:10.1016/j.comppsych.2009.11.008

44. Kiy A, Wilhelm O, Hildebrandt A, Reuter M, Sommer W (2013) On the genetic basis of face cognition and its relation to fluid cognitive abilities. Genes Brain Behav 12(4):438-445. doi:10.1111/gbb.12034

45. Shih JC (1991) Molecular basis of human MAO A and B. Neuropsychopharmacol Offi Publ Am Coll Neuropsychopharmacol 4(1):1-7

46. Zhu Q, Shih JC (1997) An extensive repeat structure downregulates human monoamine oxidase a promoter activity independent of an initiator-like sequence. J Neurochem 69(4):1368-1373

47. Brummett BH, Krystal AD, Siegler IC, Kuhn C, Surwit RS, Zuchner S, Ashley-Koch A, Barefoot JC, Williams RB (2007) Associations of a regulatory polymorphism of monoamine oxidase-A gene promoter (MAOA-uVNTR) with symptoms of depression and sleep quality. Psychosom Med 69(5):396-401. doi:10.1097/PSY.0b013e31806d040b

48. Shih JC, Chen K, Ridd MJ (1999) Role of MAO A and B in neurotransmitter metabolism and behavior. Pol J Pharmacol 51(1): 25-29

49. Brummett BH, Boyle SH, Siegler IC, Kuhn CM, Surwit RS, Garrett ME, Collins A, Ashley-Koch A, Williams RB (2008) HPA axis function in male caregivers: effect of the monoamine oxidase-A gene promoter (MAOA-uVNTR). Biol Psychol 79(2):250-255. doi:10.1016/j.biopsycho.2008.06.004

50. Lavigne JV, Herzing LB, Cook EH, Lebailly SA, Gouze KR, Hopkins J, Bryant FB (2013) Gene x environment effects of serotonin transporter, dopamine receptor D4, and monoamine oxidase A genes with contextual and parenting risk factors on symptoms of oppositional defiant disorder, anxiety, and depression in a community sample of 4-year-old children. Dev Psychopathol 25(2):555575. doi:10.1017/S0954579412001241

51. Cicchetti D, Rogosch FA, Thibodeau EL (2012) The effects of child maltreatment on early signs of antisocial behavior: genetic moderation by tryptophan hydroxylase, serotonin transporter, and monoamine oxidase A genes. Dev Psychopathol 24(3):907-928. doi:10. 1017/S0954579412000442

52. Huang SY, Lin WW, Wan FJ, Chang AJ, Ko HC, Wang TJ, Wu PL, $\mathrm{Lu}$ RB (2007) Monoamine oxidase-A polymorphisms might modify the association between the dopamine D2 receptor gene and alcohol dependence. J Psychiatry Neurosci JPN 32(3):185-192

53. Vanyukov MM, Maher BS, Devlin B, Tarter RE, Kirillova GP, Yu LM, Ferrell RE (2004) Haplotypes of the monoamine oxidase genes and the risk for substance use disorders. Am J Med Genet Part B Neuropsychiatric Genet Off Publ Int Soc Psychiatr Genet 125B(1): 120-125. doi:10.1002/ajmg.b.20105

54. Batel P, Houchi H, Daoust M, Ramoz N, Naassila M, Gorwood P (2008) A haplotype of the DRD1 gene is associated with alcohol dependence. Alcohol Clin Exp Res 32(4):567-572. doi:10.1111/j. 1530-0277.2008.00618.x

55. Kim DJ, Park BL, Yoon S, Lee HK, Joe KH, Cheon YH, Gwon DH, Cho SN, Lee HW, NamGung S, Shin HD (2007) 5' UTR polymorphism of dopamine receptor D1 (DRD1) associated with severity and temperament of alcoholism. Biochem Biophys Res Commun 357(4):1135-1141. doi:10.1016/j.bbrc.2007.04.074

56. Peng S, Du J, Jiang H, Fu Y, Chen H, Sun H, Wang D, Yu S, Zhao M (2013) The dopamine receptor D1 gene is associated with the length of interval between first heroin use and onset of dependence in Chinese Han heroin addicts. J Neural Transm 120(11):15911598. doi:10.1007/s00702-013-1029-6

57. Jacobs MM, Okvist A, Horvath M, Keller E, Bannon MJ, Morgello S, Hurd YL (2013) Dopamine receptor D1 and postsynaptic density gene variants associate with opiate abuse and striatal expression levels. Mol Psychiatry 18(11):1205-1210. doi:10.1038/mp.2012. 140
58. Huang W, Ma JZ, Payne TJ, Beuten J, Dupont RT, Li MD (2008) Significant association of DRD1 with nicotine dependence. Hum Genet 123(2):133-140. doi:10.1007/s00439-007-0453-9

59. Ni X, Trakalo JM, Mundo E, Macciardi FM, Parikh S, Lee L, Kennedy JL (2002) Linkage disequilibrium between dopamine D1 receptor gene (DRD1) and bipolar disorder. Biol Psychiatry 52(12): $1144-1150$

60. Neville MJ, Johnstone EC, Walton RT (2004) Identification and characterization of ANKK1: a novel kinase gene closely linked to DRD2 on chromosome band 11q23.1. Hum Mutat 23(6):540-545. doi:10.1002/humu.20039

61. Huang W, Payne TJ, Ma JZ, Beuten J, Dupont RT, Inohara N, Li MD (2009) Significant association of ANKK1 and detection of a functional polymorphism with nicotine dependence in an AfricanAmerican sample. Neuropsychopharmacol Off Publ Am Coll Neuropsychopharmacol 34(2):319-330. doi:10.1038/npp.2008.37

62. Noble EP, Blum K, Ritchie T, Montgomery A, Sheridan PJ (1991) Allelic association of the $\mathrm{D} 2$ dopamine receptor gene with receptorbinding characteristics in alcoholism. Arch Gen Psychiatry 48(7): 648-654

63. Montag C, Markett S, Basten U, Stelzel C, Fiebach C, Canli T, Reuter M (2010) Epistasis of the DRD2/ANKK1 Taq Ia and the BDNF Val66Met polymorphism impacts novelty seeking and harm avoidance. Neuropsychopharmacol Off Publ Am Coll Neuropsychopharmacol 35(9):1860-1867. doi:10.1038/npp.2010. 55

64. Jonsson EG, Nothen MM, Grunhage F, Farde L, Nakashima Y, Propping P, Sedvall GC (1999) Polymorphisms in the dopamine D2 receptor gene and their relationships to striatal dopamine receptor density of healthy volunteers. Mol Psychiatry 4 (3):290-296

65. Duan J, Wainwright MS, Comeron JM, Saitou N, Sanders AR, Gelernter J, Gejman PV (2003) Synonymous mutations in the human dopamine receptor D2 (DRD2) affect mRNA stability and synthesis of the receptor. Hum Mol Genet 12(3):205-216

66. Hirvonen M, Laakso A, Nagren K, Rinne JO, Pohjalainen T, Hietala J (2004) C957T polymorphism of the dopamine D2 receptor (DRD2) gene affects striatal DRD2 availability in vivo. Mol Psychiatry 9(12):1060-1061. doi:10.1038/sj.mp.4001561

67. Hill SY, Hoffman EK, Zezza N, Thalamuthu A, Weeks DE, Matthews AG, Mukhopadhyay I (2008) Dopaminergic mutations: within-family association and linkage in multiplex alcohol dependence families. Am J Med Genet Part B Neuropsychiatr Genet Off Publ Int Soc Psychiatr Genet 147B(4):517-526. doi:10.1002/ajmg. b. 30630

68. Kraschewski A, Reese J, Anghelescu I, Winterer G, Schmidt LG, Gallinat J, Finckh U, Rommelspacher H, Wernicke C (2009) Association of the dopamine D2 receptor gene with alcohol dependence: haplotypes and subgroups of alcoholics as key factors for understanding receptor function. Pharmacogenet Genomics 19(7): 513-527

69. Kazantseva A, Gaysina D, Malykh S, Khusnutdinova E (2011) The role of dopamine transporter (SLC6A3) and dopamine D2 receptor/ ankyrin repeat and kinase domain containing 1 (DRD2/ANKK1) gene polymorphisms in personality traits. Prog NeuroPsychopharmacol Biol Psychiatry 35(4):1033-1040. doi:10.1016/ j.pnpbp.2011.02.013

70. Vengeliene V, Leonardi-Essmann F, Perreau-Lenz S, GebickeHaerter P, Drescher K, Gross G, Spanagel R (2006) The dopamine D3 receptor plays an essential role in alcohol-seeking and relapse. FASEB J Off Publ Fed Am Soc Exp Biol 20(13):2223-2233. doi: 10.1096/fj.06-6110com

71. Joyce PR, Rogers GR, Miller AL, Mulder RT, Luty SE, Kennedy MA (2003) Polymorphisms of DRD4 and DRD3 and risk of avoidant and obsessive personality traits and disorders. Psychiatry Res 119(1-2):1-10 
72. Retz W, Rosler M, Supprian T, Retz-Junginger P, Thome J (2003) Dopamine D3 receptor gene polymorphism and violent behavior: relation to impulsiveness and ADHD-related psychopathology. J Neural Transm 110(5):561-572. doi:10.1007/s00702-002-0805-5

73. Spangler R, Goddard NL, Avena NM, Hoebel BG, Leibowitz SF (2003) Elevated D3 dopamine receptor mRNA in dopaminergic and dopaminoceptive regions of the rat brain in response to morphine. Brain Res Mol Brain Res 111(1-2):74-83

74. Wang E, Ding YC, Flodman P, Kidd JR, Kidd KK, Grady DL, Ryder OA, Spence MA, Swanson JM, Moyzis RK (2004) The genetic architecture of selection at the human dopamine receptor D4 (DRD4) gene locus. Am J Hum Genet 74(5):931-944. doi:10. 1086/420854

75. Chen CS, Burton M, Greenberger E, Dmitrieva J (1999) Population migration and the variation of dopamine D4 receptor (DRD4) allele frequencies around the globe. Evol Hum Behav 20(5):309-324

76. Eisenberg DT, Campbell B, Gray PB, Sorenson MD (2008) Dopamine receptor genetic polymorphisms and body composition in undernourished pastoralists: an exploration of nutrition indices among nomadic and recently settled Ariaal men of northern Kenya. BMC Evol Biol 8:173. doi:10.1186/1471-2148-8-173

77. Munafo MR, Yalcin B, Willis-Owen SA, Flint J (2008) Association of the dopamine D4 receptor (DRD4) gene and approach-related personality traits: meta-analysis and new data. Biol Psychiatry 63 (2):197-206. doi:10.1016/j.biopsych.2007.04.006

78. Posner MI, Rothbart MK, Sheese BE, Voelker P (2012) Control networks and neuromodulators of early development. Dev Psychol 48(3):827-835. doi:10.1037/a0025530

79. Schoots O, Van Tol HH (2003) The human dopamine D4 receptor repeat sequences modulate expression. Pharmacogenomics J 3(6): 343-348. doi:10.1038/sj.tpj.6500208

80. Oak JN, Oldenhof J, Van Tol HH (2000) The dopamine D(4) receptor: one decade of research. Eur J Pharmacol 405(1-3):303327

81. Mackillop J, Menges DP, McGeary JE, Lisman SA (2007) Effects of craving and DRD4 VNTR genotype on the relative value of alcohol: an initial human laboratory study. Behav Brain Funct 3: 11. doi:10.1186/1744-9081-3-11

82. Lusher JM, Chandler C, Ball D (2001) Dopamine D4 receptor gene (DRD4) is associated with Novelty Seeking (NS) and substance abuse: the saga continues. Mol Psychiatry 6(5):497-499. doi:10. 1038/sj.mp.4000918

83. Biederman J, Petty CR, Ten Haagen KS, Small J, Doyle AE, Spencer T, Mick E, Monuteaux MC, Smoller JW, Faraone SV (2009) Effect of candidate gene polymorphisms on the course of attention deficit hyperactivity disorder. Psychiatry Res 170(2-3): 199-203. doi:10.1016/j.psychres.2008.12.016

84. Grzywacz A, Kucharska-Mazur J, Samochowiec J (2008) Association studies of dopamine D4 receptor gene exon 3 in patients with alcohol dependence. Psychiatr Pol 42(3):453-461

85. Kotler M, Cohen H, Segman R, Gritsenko I, Nemanov L, Lerer B, Kramer I, Zer-Zion M, Kletz I, Ebstein RP (1997) Excess dopamine D4 receptor (D4DR) exon III seven repeat allele in opioiddependent subjects. Mol Psychiatry 2(3):251-254

86. Kawarai T, Kawakami H, Yamamura Y, Nakamura S (1997) Structure and organization of the gene encoding human dopamine transporter. Gene 195:11-18

87. Moron JA, Brockington A, Wise RA, Rocha BA, Hope BT (2002) Dopamine uptake through the norepinephrine transporter in brain regions with low levels of the dopamine transporter: evidence from knock-out mouse lines. J Neurosci Off J Soc Neurosci 22(2):389395

88. Vandenbergh DJ, Persico AM, Hawkins AL, Griffin CA, Li X, Jabs EW, Uhl GR (1992) Human dopamine transporter gene (DAT1) maps to chromosome 5p15.3 and displays a VNTR. Genomics 14 (4):1104-1106
89. Torres GE, Gainetdinov RR, Caron MG (2003) Plasma membrane monoamine transporters: structure, regulation and function. Nat Rev Neurosci 4(1):13-25. doi:10.1038/nrn1008

90. Sonders MS, Zhu SJ, Zahniser NR, Kavanaugh MP, Amara SG (1997) Multiple ionic conductances of the human dopamine transporter: the actions of dopamine and psychostimulants. J Neurosci Off J Soc Neurosci 17(3):960-974

91. Wheeler DD, Edwards AM, Chapman BM, Ondo JG (1993) A model of the sodium dependence of dopamine uptake in rat striatal synaptosomes. Neurochem Res 18(8):927-936

92. Ciliax BJ, Drash GW, Staley JK, Haber S, Mobley CJ, Miller GW, Mufson EJ, Mash DC, Levey AI (1999) Immunocytochemical localization of the dopamine transporter in human brain. J Comp Neurol 409(1):38-56

93. Liu Z, Yan SF, Walker JR, Zwingman TA, Jiang T, Li J, Zhou Y (2007) Study of gene function based on spatial co-expression in a high-resolution mouse brain atlas. BMC Syst Biol 1:19. doi:10. 1186/1752-0509-1-19

94. Kawarai T, Kawakami H, Yamamura Y, Nakamura S (1997) Structure and organization of the gene encoding human dopamine transporter. Gene 195(1):11-18

95. Sano A, Kondoh K, Kakimoto Y, Kondo I (1993) A 40-nucleotide repeat polymorphism in the human dopamine transporter gene. Hum Genet 91(4):405-406

96. Miller GM, Madras BK (2002) Polymorphisms in the 3'-untranslated region of human and monkey dopamine transporter genes affect reporter gene expression. Mol Psychiatry 7(1):44-55. doi:10.1038/ $\mathrm{sj} / \mathrm{mp} / 4000921$

97. Sacchetti P, Mitchell TR, Granneman JG, Bannon MJ (2001) Nurr1 enhances transcription of the human dopamine transporter gene through a novel mechanism. J Neurochem 76(5):1565-1572

98. Gainetdinov RR, Wetsel WC, Jones SR, Levin ED, Jaber M, Caron MG (1999) Role of serotonin in the paradoxical calming effect of psychostimulants on hyperactivity. Science (New York, NY) 283 (5400):397-401

99. Greenwood TA, Alexander M, Keck PE, McElroy S, Sadovnick AD, Remick RA, Kelsoe JR (2001) Evidence for linkage disequilibrium between the dopamine transporter and bipolar disorder. Am J Med Genet 105(2):145-151

100. Yang B, Chan RC, Jing J, Li T, Sham P, Chen RY (2007) A metaanalysis of association studies between the 10-repeat allele of a VNTR polymorphism in the $3^{\prime}$-UTR of dopamine transporter gene and attention deficit hyperactivity disorder. Am J Med Genet Part B Neuropsychiatr Genet Off publ Int Soc Psychiatr Genet 144B(4): 541-550. doi:10.1002/ajmg.b.30453

101. Sander T, Harms H, Podschus J, Finckh U, Nickel B, Rolfs A, Rommelspacher H, Schmidt LG (1997) Allelic association of a dopamine transporter gene polymorphism in alcohol dependence with withdrawal seizures or delirium. Biol Psychiatry 41(3):299304

102. Ueno S, Nakamura M, Mikami M, Kondoh K, Ishiguro H, Arinami T, Komiyama T, Mitsushio H, Sano A, Tanabe H (1999) Identification of a novel polymorphism of the human dopamine transporter (DAT1) gene and the significant association with alcoholism. Mol Psychiatry 4(6):552-557

103. Ueno S (2003) Genetic polymorphisms of serotonin and dopamine transporters in mental disorders. J Med Invest 50(1-2):25-31

104. Beaver KM, Wright JP, DeLisi M (2008) Delinquent peer group formation: evidence of a gene $\mathrm{x}$ environment correlation. J Genet Psychol 169(3):227-244. doi:10.3200/GNTP. 169.3.227-244

105. Laasonen-Balk T, Kuikka J, Viinamaki H, Husso-Saastamoinen M, Lehtonen J, Tiihonen J (1999) Striatal dopamine transporter density in major depression. Psychopharmacology 144(3):282-285

106. Bannon MJ, Poosch MS, Xia Y, Goebel DJ, Cassin B, Kapatos G (1992) Dopamine transporter mRNA content in human substantia 
nigra decreases precipitously with age. Proc Natl Acad Sci U S A 89 (15):7095-7099

107. Kilty JE, Lorang D, Amara SG (1991) Cloning and expression of a cocaine-sensitive rat dopamine transporter. Science (New York, NY) 254(5031):578-579

108. Kahlig KM, Javitch JA, Galli A (2004) Amphetamine regulation of dopamine transport. Combined Meas Transp Curr Transporter Imaging Support Endocytosis active Carrier J Biol Chem 279(10): 8966-8975. doi:10.1074/jbc.M303976200

109. Moore KE (1977) The actions of amphetamine on neurotransmitters: a brief review. Biol Psychiatry 12(3):451-462

110. Johnson LA, Guptaroy B, Lund D, Shamban S, Gnegy ME (2005) Regulation of amphetamine-stimulated dopamine efflux by protein kinase C beta. J Biol Chem 280(12):10914-10919. doi:10.1074/jbc. M413887200

111. Kahlig KM, Binda F, Khoshbouei H, Blakely RD, McMahon DG, Javitch JA, Galli A (2005) Amphetamine induces dopamine efflux through a dopamine transporter channel. Proc Natl Acad Sci U S A 102(9):3495-3500. doi:10.1073/pnas.0407737102

112. Schultz W (1998) Predictive reward signal of dopamine neurons. J Neurophysiol 80(1):1-27

113. Vandenbergh DJ (1998) Molecular cloning of neurotransmitter transporter genes: beyond coding region of cDNA. Methods Enzymol 296:498-514

114. Michelhaugh SK, Fiskerstrand C, Lovejoy E, Bannon MJ, Quinn JP (2001) The dopamine transporter gene (SLC6A3) variable number of tandem repeats domain enhances transcription in dopamine neurons. J Neurochem 79(5):1033-1038

115. Guindalini C, Howard M, Haddley K, Laranjeira R, Collier D, Ammar N, Craig I, O'Gara C, Bubb VJ, Greenwood T, Kelsoe J, Asherson P, Murray RM, Castelo A, Quinn JP, Vallada H, Breen G (2006) A dopamine transporter gene functional variant associated with cocaine abuse in a Brazilian sample. Proc Natl Acad Sci U S A 103(12):4552-4557. doi:10.1073/pnas.0504789103

116. Vandenbergh DJ, Kozlowski LT, Bennett CJ, Grant MD, Strasser AA, O'Connor R, Stauffer RL, Vogler GP (2002) DAT's not all, but it may be more than we realize. Nicotine Tob Res Off J Soc Res Nicotine Tob 4(3):251-252. doi:10.1080/14622200210141248

117. Cook EH Jr, Stein MA, Krasowski MD, Cox NJ, Olkon DM, Kieffer JE, Leventhal BL (1995) Association of attention-deficit disorder and the dopamine transporter gene. Am J Hum Genet 56 (4):993-998

118. Wang GJ, Volkow ND, Wigal T, Kollins SH, Newcorn JH, Telang F, Logan J, Jayne M, Wong CT, Han H, Fowler JS, Zhu W, Swanson JM (2013) Long-term stimulant treatment affects brain dopamine transporter level in patients with attention deficit hyperactive disorder. PLoS One 8(5):e63023. doi:10. 1371/journal.pone. 0063023

119. Watanabe M, Macmura K, Kanbara K, Tamayama T, Hayasaki H (2002) GABA and GABA receptors. In: Jeon KW (ed) Int Rev Cytol, vol 213. pp 1-47

120. Szabadics J, Varga C, Molnar G, Olah S, Barzo P, Tamas G (2006) Excitatory effect of GABAergic axo-axonic cells in cortical microcircuits. Science (New York, NY) 311(5758):233-235. doi:10.1126/ science. 1121325

121. Li K, Xu E (2008) The role and the mechanism of gammaaminobutyric acid during central nervous system development. Neurosci Bull 24(3):195-200

122. Schousboe A, Waagepetersen HS (2007) GABA: homeostatic and pharmacological aspects. Prog Brain Res 160:9-19. doi:10.1016/ S0079-6123(06)60002-2

123. Petroff OA (2002) GABA and glutamate in the human brain Neuroscientist Rev J Bringing Neurobiol Neurol Psychiatry 8(6): 562-573

124. Bown AW, Shelp BJ (1997) The metabolism and functions of [gamma]-aminobutyric acid. Plant Physiol 115(1):1-5
125. Foster AC, Kemp JA (2006) Glutamate- and GABA-based CNS therapeutics. Curr Opin Pharmacol 6(1):7-17. doi:10.1016/j.coph. 2005.11.005

126. Chapouthier G, Venault P (2001) A pharmacological link between epilepsy and anxiety? Trends Pharmacol Sci 22(10):491-493

127. Muller EE, Locatelli V, Cocchi D (1999) Neuroendocrine control of growth hormone secretion. Physiol Rev 79(2):511-607

128. Powers ME, Yarrow JF, McCoy SC, Borst SE (2008) Growth hormone isoform responses to GABA ingestion at rest and after exercise. Med Sci Sports Exerc 40(1):104-110. doi:10.1249/mss. 0b013e318158b518

129. White FJ (1996) Synaptic regulation of mesocorticolimbic dopamine neurons. Annu Rev Neurosci 19:405-436. doi:10.1146/ annurev.ne.19.030196.002201

130. Ikemoto S, Kohl RR, McBride WJ (1997) GABA(A) receptor blockade in the anterior ventral tegmental area increases extracellular levels of dopamine in the nucleus accumbens of rats. J Neurochem 69(1):137-143

131. Theile JW, Morikawa H, Gonzales RA, Morrisett RA (2008) Ethanol enhances GABAergic transmission onto dopamine neurons in the ventral tegmental area of the rat. Alcohol Clin Exp Res 32(6): 1040-1048. doi:10.1111/j.1530-0277.2008.00665.x

132. Johnson SW, North RA (1992) Opioids excite dopamine neurons by hyperpolarization of local interneurons. J Neurosci Off $\mathrm{J}$ Soc Neurosci 12(2):483-488

133. Namkoong K, Cheon KA, Kim JW, Jun JY, Lee JY (2008) Association study of dopamine D2, D4 receptor gene, GABAA receptor beta subunit gene, serotonin transporter gene polymorphism with children of alcoholics in Korea: a preliminary study. Alcohol (Fayetteville, NY) 42(2):77-81. doi:10.1016/j.alcohol. 2008.01.004

134. Noble EP, Zhang X, Ritchie T, Lawford BR, Grosser SC, Young RM, Sparkes RS (1998) D2 dopamine receptor and GABA(A) receptor beta3 subunit genes and alcoholism. Psychiatry Res 81 (2):133-147

135. Konishi T, Calvillo M, Leng AS, Lin KM, Wan YJ (2004) Polymorphisms of the dopamine D2 receptor, serotonin transporter, and GABA(A) receptor beta(3) subunit genes and alcoholism in Mexican-Americans. Alcohol (Fayetteville, NY) 32(1):45-52. doi: 10.1016/j.alcohol.2003.11.002

136. Edenberg HJ, Dick DM, Xuei X, Tian H, Almasy L, Bauer LO, Crowe RR, Goate A, Hesselbrock V, Jones K, Kwon J, Li TK, Nurnberger JI Jr, O’Connor SJ, Reich T, Rice J, Schuckit MA, Porjesz B, Foroud T, Begleiter H (2004) Variations in GABRA2, encoding the alpha 2 subunit of the GABA(A) receptor, are associated with alcohol dependence and with brain oscillations. Am J Hum Genet 74(4):705-714. doi:10.1086/383283

137. Han DH, Bolo N, Daniels MA, Lyoo IK, Min KJ, Kim CH, Renshaw PF (2008) Craving for alcohol and food during treatment for alcohol dependence: modulation by $\mathrm{T}$ allele of $1519 \mathrm{~T}>\mathrm{C}$ GABAAalpha6. Alcohol Clin Exp Res 32(9):1593-1599. doi:10. 1111/j.1530-0277.2008.00734.x

138. Enoch MA, Baghal B, Yuan Q, Goldman D (2013) A factor analysis of global GABAergic gene expression in human brain identifies specificity in response to chronic alcohol and cocaine exposure. PLoS One 8(5):e64014. doi:10.1371/journal.pone. 0064014

139. Dhawan BN, Cesselin F, Raghubir R, Reisine T, Bradley PB, Portoghese PS, Hamon M (1996) International union of pharmacology. XII Classification Opioid Recept Pharmacological Rev 48 (4):567-592

140. Janecka A, Fichna J, Janecki T (2004) Opioid receptors and their ligands. Curr Top Med Chem 4(1):1-17

141. Waldhoer M, Bartlett SE, Whistler JL (2004) Opioid receptors. Annu Rev Biochem 73:953-990. doi:10.1146/annurev.biochem. 73.011303 .073940 
142. Goldstein A, Lowney LI, Pal BK (1971) Stereospecific and nonspecific interactions of the morphine congener levorphanol in subcellular fractions of mouse brain. Proc Natl Acad Sci U S A 68(8): $1742-1747$

143. Pert CB, Snyder SH (1973) Opiate receptor: demonstration in nervous tissue. Science (New York, NY) 179(4077):1011-1014

144. Terenius L (1973) Stereospecific interaction between narcotic analgesics and a synaptic plasm a membrane fraction of rat cerebral cortex. Acta Pharmacol Toxicol (Copenh) 32(3):317320

145. Simon EJ, Hiller JM, Edelman I (1973) Stereospecific binding of the potent narcotic analgesic $(3 \mathrm{H})$ Etorphine to rat-brain homogenate. Proc Natl Acad Sci U S A 70(7):1947-1949

146. Corbett AD, Henderson G, McKnight AT, Paterson SJ (2006) 75 years of opioid research: the exciting but vain quest for the Holy Grail. Br J Pharmacol 147(Suppl 1):S153-S162. doi:10. 1038/sj.bjp.0706435

147. Girdlestone D (2003) Opioid Receptors. In: Cox BM, Chavkin C, Christie MJ et al (eds) The IUPHAR Compendium of Receptor Characterization and Classification, 2nd edn. IUPHAR Media, London, pp 321-333

148. Opioid Receptors (2008) IUPHAR Database; International Union of Pharmacology

149. Kapur S, Sharad S, Singh RA, Gupta AK (2007) A118g polymorphism in mu opioid receptor gene (oprm1): association with opiate addiction in subjects of Indian origin. J Integr Neurosci 6(4):511522

150. Mura E, Govoni S, Racchi M, Carossa V, Ranzani GN, Allegri M, van Schaik RH (2013) Consequences of the $118 \mathrm{~A}>\mathrm{G}$ polymorphism in the OPRM1 gene: translation from bench to bedside? J Pain Res 6:331-353. doi:10.2147/JPR.S42040

151. De Capraris A, Cinnella G, Marolla A, Salatto P, Da Lima S, Vetuschi P, Consoletti L, Gesualdo L, Dambrosio M (2011) Micro opioid receptor A118G polymorphism and postoperative pain: opioids' effects on heterozygous patients. Int J Immunopathol Pharmacol 24(4):993-1004

152. Liu YC, Wang WS (2012) Human mu-opioid receptor gene A118G polymorphism predicts the efficacy of tramadol/acetaminophen combination tablets (ultracet) in oxaliplatin-induced painful neuropathy. Cancer 118(6):1718-1725. doi:10.1002/cncr.26430

153. Setiawan E, Pihl RO, Benkelfat C, Leyton M (2012) Influence of the OPRM1 A118G polymorphism on alcohol-induced euphoria, risk for alcoholism and the clinical efficacy of naltrexone. Pharmacogenomics 13(10):1161-1172. doi:10.2217/ pgs. 12.99

154. Kranzler HR, Gelernter J, O’Malley S, Hernandez-Avila CA, Kaufman D (1998) Association of alcohol or other drug dependence with alleles of the mu opioid receptor gene (OPRM1). Alcohol Clin Exp Res 22(6):1359-1362

155. Teo YY (2008) Common statistical issues in genome-wide association studies: a review on power, data quality control, genotype calling and population structure. Curr Opin Lipidol 19(2):133-143. doi:10.1097/MOL.0b013e3282f5dd77

156. Archer T, Oscar-Berman M, Blum K, Gold M (2012) Neurogenetics and epigenetics in impulsive behaviour: impact on reward circuitry. J Genet Syndr Gene Ther 3(3):1000115. doi:10.4172/2157-7412. 1000115

157. Archer T, Oscar-Berman M, Blum K, Gold M (2013) Epigenetic Modulation of Mood Disorders. J Genet Syndr Gene Ther 4 (120). doi: $10.4172 / 2157-7412.1000120$

158. Archer T, Oscar-Berman M, Blum K (2011) Epigenetics in developmental disorder: ADHD and Endophenotypes. J Genet Syndr Gene Ther 2 (104)

159. Dackis CA, Gold MS (1988) Biological aspects of cocaine addiction. In: Volkow ND, Swann AC (eds) Cocaine in the brain. Rutgers University Press, New Brunswick
160. Neill DB, Peay LA, Gold MS (1978) Identification of a subregion within rat neostriatum for the dopaminergic modulation of lateral hypothalamic self-stimulation. Brain Res 153(3):515-528

161. Miller NS, Gold MS (1991) Dual diagnoses: psychiatric syndromes in alcoholism and drug addiction. Am Fam Physician 43(6):20712076

162. Miller NS, Dackis CA, Gold MS (1987) The relationship of addiction, tolerance, and dependence to alcohol and drugs: a neurochemical approach. J Subst Abus Treat 4(3-4):197-207

163. Miller NS, Gold MS (1998) Management of withdrawal syndromes and relapse prevention in drug and alcohol dependence. Am Fam Physician 58(1):139-146

164. Buck K, Lischka T, Dorow J, Crabbe J (2000) Mapping quantitative trait loci that regulate sensitivity and tolerance to quinpirole, a dopamine mimetic selective for $\mathrm{D}(2) / \mathrm{D}(3)$ receptors. Am J Med Genet 96(5):696-705

165. Phillips TJ, Crabbe JC, Metten P, Belknap JK (1994) Localization of genes affecting alcohol drinking in mice. Alcohol Clin Exp Res 18 (4):931-941

166. Crabbe JC, Phillips TJ, Harris RA, Arends MA, Koob GF (2006) Alcohol-related genes: contributions from studies with genetically engineered mice. Addict Biol 11(3-4):195-269

167. Feero WG (2014) Clinical application of whole-genome sequencing: proceed with care. JAMA 311(10):1017-1019

168. Hall FS, Sora I, Uhl GR (2001) Ethanol consumption and reward are decreased in mu-opiate receptor knockout mice. Psychopharmacology (Berl) 154(1):43-49

169. Reynolds GP, McGowan OO, Dalton CF (2013) Pharmacogenomics in psychiatry: the relevance of receptor and transporter polymorphisms. Br J Clin Pharmacol. doi:10.1111/bcp.12312

170. Han S, Yang BZ, Kranzler HR, Liu X, Zhao H, Farrer LA, Boerwinkle E, Potash JB, Gelernter J (2013) Integrating GWASs and human protein interaction networks identifies a gene subnetwork underlying alcohol dependence. Am J Hum Genet 93(6):1027-1034

171. Uhl GR, Drgonova J, Hall FS (2014) Curious cases: altered doseresponse relationships in addiction genetics. Pharmacol Ther 141 (3):335-346

172. Ehlers CL, Gizer IR (2013) Evidence for a genetic component for substance dependence in Native Americans. Am J Psychiatry 170 (2):154-164

173. Zhao Z, Guo AY, van den Oord EJ, Aliev F, Jia P, Edenberg HJ, Riley BP, Dick DM, Bettinger JC, Davies AG, Grotewiel MS, Schuckit MA, Agrawal A, Kramer J, Nurnberger JI Jr, Kendler KS, Webb BT, Miles MF (2012) Multi-species data integration and gene ranking enrich significant results in an alcoholism genome-wide association study. BMC Genomics 13(Suppl 8):S16

174. Agrawal A, Wetherill L, Bucholz KK, Kramer J, Kuperman S, Lynskey MT, Nurnberger JI Jr, Schuckit M, Tischfield JA, Edenberg HJ, Foroud T, Bierut LJ (2013) Genetic influences on craving for alcohol. Addict Behav 38(2):1501-1508

175. Li CY, Zhou WZ, Zhang PW, Johnson C, Wei L, Uhl GR (2011) Meta-analysis and genome-wide interpretation of genetic susceptibility to drug addiction. BMC Genomics 12:508

176. Li CY, Mao X, Wei L (2008) Genes and (common) pathways underlying drug addiction. PLoS Comput Biol 4(1):e2

177. Derringer J, Krueger RF, Dick DM, Aliev F, Grucza RA, Saccone S, Agrawal A, Edenberg HJ, Goate AM, Hesselbrock VM, Kramer JR, Lin P, Neuman RJ, Nurnberger JI Jr, Rice JP, Tischfield JA, GENEVA consortium, Bierut LJ (2012) The aggregate effect of dopamine genes on dependence symptoms among cocaine users: cross-validation of a candidate system scoring approach. Behav Genet 42(4):626-635

178. Feltus FA (2014) Systems genetics: A paradigm to improve discovery of candidate genes and mechanisms underlying complex traits. Plant Sci 223C:45-48. doi:10.1016/j.plantsci.2014.03.003 
179. Jordi E, Heiman M, Marion-Poll L, Guermonprez P, Cheng SK, Nairn AC, Greengard P, Girault JA (2013) Differential effects of cocaine on histone posttranslational modifications in identified populations of striatal neurons. Proc Natl Acad Sci U S A 110(23):9511-9516

180. Byrnes J, Johnson NL, Carini LM, Byrnes EM (2013) Multigenerational effects of adolescent morphine exposure on dopamine D2 receptor function. Psychopharmacology (Berl) 227(2):263-272

181. DiNieri JA, Wang X, Szutorisz H, Spano SM, Kaur J, Casaccia P, Dow-Edwards D, Hurd YL (2011) Maternal cannabis use alters ventral striatal dopamine D2 gene regulation in the offspring. Biol Psychiatry 70(8):763-769

182. Belsky J, Beaver KM (2011) Cumulative-genetic plasticity, parenting and adolescent self-regulation. J Child Psychol Psychiatry 52 (5):619-626

183. Liu JC, Baker RE, Chow W, Sun CK, Elsholtz HP (2005) Epigenetic mechanisms in the dopamine D2 receptor-dependent inhibition of the prolactin gene. Mol Endocrinol 19(7):1904-1917

184. Li J, Guo Y, Schroeder FA, Youngs RM, Schmidt TW, Ferris C, Konradi C, Akbarian S (2004) Dopamine D2-like antagonists induce chromatin remodeling in striatal neurons through cyclic AMP-protein kinase A and NMDA receptorsignaling. J Neurochem 90(5):1117-1131

185. Nestler EJ (2012) Transcriptional mechanisms of drug addiction. Clin Psychopharmacol Neurosci 10(3):136-143

186. Downs B, Oscar-Berman M, Waite R, Madigan M, Giordano J, Beley T, Jones S, Simpatico T, Hauser M, Borsten J, Febo M, Braverman E, Lohmann R, Dushaj K, Helman M, Barh D, Schoenthaler S, Han D, Blum K (2013) Have we hatched the addiction egg: reward deficiency syndrome solution system ${ }^{\mathrm{TM}}$. J Genet Syndr Gene Ther 4(136): 14318

187. Barr CL, Kidd KK (1993) Population frequencies of the A1 allele at the dopamine D2 receptor locus. Biol Psychiatry 34(4):204-209

188. Belcher AM, Volkow ND, Moeller FG, Ferré S (2014) Personality traits and vulnerability or resilience to substance use disorders. Trends Cogn Sci

189. Dahlgren A, Wargelius HL, Berglund KJ, Fahlke C, Blennow K, Zetterberg H, Oreland L, Berggren U, Balldin J (2011) Do alcoholdependent individuals with DRD2 A1 allele have an increased risk of relapse? a pilot study. Alcohol Alcohol 46(5):509-513 